See discussions, stats, and author profiles for this publication at: https://www.researchgate.net/publication/286912730

\title{
Emergence of blueschists on Earth linked to secular changes in oceanic crust composition
}

Article in Nature Geoscience · January 2016

DOI: 10.1038/ngeo2605

\section{CITATIONS}

43

2 authors:

Richard Mark Palin

University of Oxford

68 PUBLICATIONS 790 CITATIONS

SEE PROFILE
READS

642

R. W. White

Johannes Gutenberg-Universität Mainz

99 PUBLICATIONS 6,665 CITATIONS

SEE PROFILE

Some of the authors of this publication are also working on these related projects:

Project Secular changes in metamorphic processes and products View project

Project Thermodynamic modelling of partial melting in metabasic rocks View project 
This is a pre-print version of the peer-reviewed article:

Palin, R.M., White, R.W., 2016. Emergence of blueschists on Earth linked to secular changes in oceanic crust composition. Nature Geoscience, v. 9, p. 60-64,

which has been published in final form at: 10.1038/ngeo2605,

It is self-archived under the terms of Sherpa/RoMEO Yellow, which allows hosting of preprints on public databases no sooner than six months after publication.

Note that some figures appear differently in the final version due to changes applied during the typesetting process.

Richard Palin (richardmpalin@gmail.com) 
1 Emergence of blueschists on Earth linked to secular changes

2 in oceanic crust composition

4 Richard M. Palin* and Richard W. White

5 Institute of Geosciences, Johannes-Gutenberg University Mainz, 55128 Mainz, Germany

$6 *$ corresponding author: richardmpalin@gmail.com

8 The oldest blueschists - metamorphic rocks formed during subduction - are of

9 Neoproterozoic age ${ }^{1}$, and 0.7 to 0.8 billion years old. Yet, subduction of oceanic crust to

10 mantle depths is thought to have occurred since the Hadean, over 4 billion years ago ${ }^{2}$.

11 Blueschists typically form under cold geothermal gradients of less than $400{ }^{\circ} \mathrm{C} \mathrm{GPa}^{-1}$, so

12 their absence in the ancient rock record is typically attributed to hotter pre-

13 Neoproterozoic mantle prohibiting such low-temperature metamorphism; however,

14 modern analogues of Archean subduction suggest that blueschist-facies metamorphic

15 conditions are attainable at the slab surface ${ }^{3}$. Here we show that the absence of

16 blueschists in the ancient geological record can be attributed to the changing

17 composition of oceanic crust throughout Earth history, which is a consequence of

18 secular cooling of the mantle since the Archean ${ }^{4}$. Oceanic crust formed on the hot, early

19 Earth would have been rich in magnesium oxide (MgO). We use phase equilibria

20 calculations to show that blueschists do not form in high-MgO rocks under subduction-

21 related geothermal gradients. Instead, the subduction of MgO-rich oceanic crust would

22 have created greenschist-like rocks - metamorphic rocks formed today at low

23 temperatures and pressures. These ancient metamorphic products can hold about $20 \%$ 
more water than younger metamorphosed oceanic crust, implying that the global

\section{hydrological cycle was more efficient in the deep geological past than today.}

Blueschists are glaucophane-bearing meta-basalts ${ }^{5,6}$ that form at high-pressure-lowtemperature $(\mathrm{H} P-\mathrm{L} T)$ conditions in the Earth, typically along geothermal gradients of $150-$ $400{ }^{\circ} \mathrm{C} / \mathrm{GPa}$. As such conditions only occur today in subduction zones, blueschists are a diagnostic petrological signature of the operation of modern-day subduction-driven plate tectonics, with the cause of their apparent absence from the first $\sim 3.8$ Gyr of Earth history being a highly controversial topic. Some workers propose that modern-day plate tectonics initiated during the Neoproterozoic ${ }^{7,8}(0.5-1.0 \mathrm{Ga})$ with the absence of subduction prior to this geodynamic transition prohibiting their formation. However, numerous studies suggest that subduction-related processes operated on the early Earth during the Palaeoarchean ${ }^{9}$ (3.23.6 Ga), the Eoarchean ${ }^{10}(3.6-4.0 \mathrm{Ga})$, and even the $\operatorname{Hadean}^{2}(>4.0 \mathrm{Ga})$. Although a hotter Archean mantle ${ }^{4}$ reputedly caused subduction to proceed along elevated geothermal gradients $^{11}$, numerical modelling shows that the thermal structure of subduction zones is primarily controlled by the convergence rate and age of subducting lithosphere, with ambient mantle temperature imparting a second-order effect ${ }^{12,13}$. Modern-day convergent margins exhibiting plate-tectonic velocities and subducted-crust ages similar to purported Archean values (see Supplementary Information) exhibit slab-top geotherms in the range $\sim 280-380$ ${ }^{\circ} \mathrm{C} / \mathrm{GPa}$ at $0.5-2.5 \mathrm{GPa}^{3}$. As such, it is sensible to consider that metamorphism of hydrated oceanic crust under such blueschist-facies $\mathrm{H} P-\mathrm{L} T$ conditions occurred during preNeoproterozoic times, the consequences of which we investigate herein. Here, we present a petrological explanation for the apparent absence of blueschists in the early-Earth geological record, which has received no consideration in previous works. Alhough higher mantle temperatures may not have appreciably affected subduction-zone thermal structures, they will have directly controlled the composition of primary crust 
generated at mid-ocean ridge (MOR) systems. Mantle potential temperatures have decreased

50 throughout Earth history from $\sim 1500-1600{ }^{\circ} \mathrm{C}$ at c. $2.5-3.0$ Ga to $\sim 1350{ }^{\circ} \mathrm{C}$ today ${ }^{4}$.

51 Consequently, oceanic crust on the early Earth is thought to have been significantly more

52 magnesian than modern MOR basalt ${ }^{15}$, which contains $\sim 8 \mathrm{wt} \% \mathrm{MgO}$ (Table $\mathrm{S} 1$ ). This

53 compositional trend has been confirmed in non-arc basalts from Archean and Proterozoic

54 greenstone terranes ${ }^{16}$.

55 We investigate the petrological effects of secular cooling by forward-modelling the

56 equilibrium (minimum Gibbs free energy) mineral assemblages that would develop during

$57 \mathrm{H} P-\mathrm{L} T$ metamorphism of four natural lithologies representative of MOR-derived oceanic

58 crust: a Palaeoarchean high-MgO basalt with $\sim 16.2 \mathrm{wt} \% \mathrm{MgO}$, a Palaeoproterozoic olivine-

59 bearing basalt with $\sim 14.1 \mathrm{wt} \% \mathrm{MgO}$, a Mesoproterozoic gabbro with $\sim 11.2 \mathrm{wt} \% \mathrm{MgO}$, and a

60 pillow basalt from the Neoproterozoic-Palaeozoic boundary with $~ 9.7$ wt\% MgO (Table S1).

61 This range in $\mathrm{MgO}$ content is similar to that proposed for geochemical models of Archean-

62 Proterozoic oceanic crust $(11-15 \mathrm{wt} \% \mathrm{MgO})^{17}$. Age and full bulk-rock compositional data are

63 given in Tables S1 and S2. From these calculated mineral assemblages, we identify different

64 metamorphic rock types that characterise potential cold and warm Archean and Proterozoic

65 subduction zones. Varying proportions of hydrous minerals that would stabilise during

66 prograde metamorphism are used to calculate fluid budgets for each descending slab and

67 constrain the $P-T$ conditions under which major dehydration reactions occur. From these

68 results, we draw important conclusions about the changing petrological character of

69 subduction-zone metamorphism and the potential efficiency of fluid transfer between the

70 hydrosphere and upper mantle throughout Earth history.

71 Metamorphic rock types calculated to be stable between $0.5-2.5 \mathrm{GPa}$ and $300-650{ }^{\circ} \mathrm{C}$

72 are shown in Fig. 1, with glaucophane stability indicated by stippled regions. Modebox plots

73 showing the proportions of minerals occurring along a warm geotherm $\left(350^{\circ} \mathrm{C} / \mathrm{GPa}\right)$ are 
given in Fig. 2. Fully labelled phase diagrams are presented in Fig. S1 and modebox plots

75 showing mineral assemblages along a cold geotherm $\left(250^{\circ} \mathrm{C} / \mathrm{GPa}\right)$ are shown in Fig. S2.

76 Additional detail regarding phase equilibria modelling procedures is given in the Methods

77 section and the Supplementary Information.

MgO-rich (Fig. 1a) and olivine-bearing basalts (Fig. 1b) only form glaucophane-bearing assemblages between $\sim 0.8-1.4 \mathrm{GPa}$ and $\sim 390-500{ }^{\circ} \mathrm{C}$. Outside of this $P-T$ range, warmsubduction assemblages in both protoliths are dominated by actinolite and chlorite - together comprising $\sim 75 \%$ modal proportion - with subsidiary (1-10\% each) lawsonite, epidote,

82 zoisite, clinopyroxene, sphene, rutile, quartz, muscovite, biotite, and/or garnet, depending on 83 metamorphic grade (Fig. 2a-b). Here, the proportion of lawsonite would be strongly

84 influenced by the $\mathrm{H}_{2} \mathrm{O}$ content of the bulk composition and would be considerably reduced if 85 the rock could not maintain fluid saturation ${ }^{18}$. Assemblages formed during cold subduction, 86 typical of $P-T$ conditions recorded by Phanerozoic and Neoproterozoic blueschists ${ }^{19}$, are 87 largely similar, though lack epidote and zoisite, and additionally contain talc and tremolite at 88 high-grade conditions (Fig. S2). Notably, deep subduction along either geotherm would form 89 garnet-pyroxenite or garnet-hornblendite (Fig. 1), not eclogite, as diopside would be stable 90 instead of omphacite (Figs $2 \mathrm{a}-\mathrm{b}$ and S2).

91 By contrast, sodic amphibole is significantly more stable in $\mathrm{MgO}$-poor $(\leq 11.2 \mathrm{wt} \%)$ 92 bulk compositions representative of Mesoproterozoic-Neoproterozoic oceanic crust (Figs 1c93 d) and diagnostic blueschist-facies assemblages occur over a wider $P-T$ range. Lawsonite94 blueschists containing up to $\sim 30 \%$ glaucophane would form during cold subduction (Fig. S2), 95 ultimately transforming to eclogite at $T>525^{\circ} \mathrm{C}$ (Fig. 1c-d). Metamorphism along a warm 96 geotherm would form epidote-blueschist in both cases, containing up to $\sim 40 \%$ glaucophane 97 (Fig. 2c-d). Calculated bulk-rock densities for all lithologies along either cold or warm 98 geotherms are remarkably similar $\left(\sim 3.10-3.15 \mathrm{~g} / \mathrm{cm}^{3}\right)$, despite the different mineralogies, and 
99 only increase significantly when garnet stabilises (Figs 2 and S2). As these densities do not

100 exceed $\sim 3.30 \mathrm{~g} / \mathrm{cm}^{3}$ proposed for Archean sub-continental lithospheric mantle ${ }^{20}$, their

101 exhumation to crustal depths should not be prohibited by a negative-buoyancy contrast;

102 however, the mechanisms of exhumation of high- $P$ rocks are poorly understood, even in

103 modern-day tectonic settings ${ }^{21}$. Differences in the petrophysical characteristics of modern and

104 ancient mantle and oceanic lithosphere ${ }^{22}$ alongside sluggish plate velocities may have

105 promoted the deep-subduction of oceanic crust, but resisted its exhumation back to the

106 surface $^{23}$. Consequently, the formation, but lack of exhumation, of high- $P$ rocks during

107 subduction may additionally have contributed to their scarcity in ancient geological terranes.

108 Nonetheless, even if exhumation readily occurred, the preservation of HP-LT mineral

109 assemblages is problematic, requiring it to be rapid, largely deformation- and fluid-free, and

110 accompanied by substantial cooling ${ }^{18}$. In particular, despite being stable over a wide range of

111 subduction-related $P-T$ conditions (Fig. 1), lawsonite is rarely preserved in exhumed rocks,

112 instead decomposing to chlorite, zoisite, paragonite, and/or quartz ${ }^{24,25}$. The petrological

113 products of subducted high-MgO and olivine-bearing ocean crust - if exhumed - may

114 therefore closely resemble those that characterise lower- $P$ greenschist-facies metabasites

115 (Figs 1 and S1), illustrating the potential for misidentification of subduction-related mafic-

116 ultramafic components of Archean greenstone belts as having formed in crustal environments.

117 However, discrimination between these tectonic scenarios should be possible on the basis of

118 constituent mineral chemistry, as actinolite compositions calculated along high- $P$ geotherms

119 for high-MgO bulk compositions are more sodic and magnesian than those at equivalent

120 temperatures in the greenschist facies (Fig. S3).

121 What consequences does this secular compositional change have for subduction-zone

122 hydrodynamics? The dehydration of subducted crustal material is a major process within the

123 global geological water cycle, directly influencing arc magmatism and the physical properties 
124 of the subducting slab and overlying mantle wedge ${ }^{13}$. Key dehydration reactions that would 125 occur during warm subduction of Archean high-MgO basalt and Neoproterozoic low-MgO

126 basalt are shown in Figs 3a and 3b, respectively, and calculated proportions of hydrous phases

127 have allowed determination of the water budgets for each descending slab (Supplementary

128 Information). Assuming that low-grade mineral assemblages in the shallow portion of the

129 subduction channel $(10-15 \mathrm{~km})$ are minimally fluid-saturated, $\sim 20 \mathrm{~mol} . \%$ of the initially

130 subducted structurally bound $\mathrm{H}_{2} \mathrm{O}$ would be released simultaneously in both protoliths via the

131 decomposition of lawsonite at $P \sim 1.1-1.2 \mathrm{GPa}$, equivalent to a depth of $40-45 \mathrm{~km}$ (Fig. S4).

132 Significant further dehydration occurs at $\sim 1.4-1.7 \mathrm{GPa}(50-60 \mathrm{~km})$ via the breakdown of

133 chlorite (and minor epidote) to produce garnet, where $40 \%$ more $\mathrm{H}_{2} \mathrm{O}$ is released over just 50 -

$13460{ }^{\circ} \mathrm{C}$ (Fig. S4). Fluid loss would continue with increasing metamorphism as amphibole

135 destabilises, with near-complete dehydration $\left(>90 \% \mathrm{H}_{2} \mathrm{O}\right.$ loss) achieved at $\sim 2.1-2.2 \mathrm{GPa}(75-$ $13680 \mathrm{~km})$.

137 It has previously been supposed that the transport of $\mathrm{H}_{2} \mathrm{O}$ from the hydrosphere into the

138 Earth's interior was significantly less efficient during the Archean than occurs today due to

139 higher mantle potential temperatures thought to have dehydrated subducted materials at

140 shallower depths ${ }^{26}$. However, numerical modelling refutes the proposition that Archean

141 subduction necessarily occurred along exceptionally hot geotherms ${ }^{3}$. Fully hydrated high-

$142 \mathrm{MgO}$ metabasalt has the capacity to hold $20 \%$ more water (5.93 wt $\%$ ) within constituent

143 hydrous phases than modern-day low-MgO metabasalt can (4.9 wt $\%)$ under equivalent $P-T$

144 conditions (Fig. S4), owing to a larger combined proportion of chlorite and amphibole (Fig.

145 2). Additionally, a bulk composition that is more magnesian and less aluminous than a

146 Neoproterozoic or modern MOR basalt (Table S2) delays the onset of garnet growth during

147 metamorphism (Fig. 1a-d), allowing chlorite to stably persist to higher temperatures and

148 dehydrate at greater depths in the subduction channel (Fig. 3). The transport of volatiles from 
149 the hydrosphere to the Earth's interior was thus likely to have been more efficient during the 150 Archean than today, in contrast to previous studies' assumptions ${ }^{26}$. Although the actual depths 151 of subduction-dehydration are contingent on the dip angle, age, and convergence rate of the 152 subducting slab ${ }^{27}$, the majority of fluid loss from the oceanic crust during Neoproterozoic and 153 Archean subduction is predicted to occur at upper-mantle depths (40-80 km).

154 Our results show for the first time that the apparent absence of blueschists from the 155 early-Earth geological record can be accounted for by the changing chemical composition of 156 oceanic crust throughout Earth history: a consequence of secular cooling of the mantle since 157 the Archean ${ }^{4}$. The prior lack of investigation into the petrological evolution of subducted 158 high-MgO basalt has restricted our understanding of early-Earth tectonics. The limited $P-T$ 159 range over which sodic amphibole forms (Fig. 1a-b), coupled with the extreme difficulty in 160 preserving lawsonite (if present) during exhumation, mean that the petrological products of 161 subduction-metamorphism in Archean-Paleoproterozoic terranes will be significantly 162 different than those in Mesoproterozoic-Phanerozoic terranes, even if formed at equivalent $163 \mathrm{H} P-\mathrm{L} T$ conditions. Such differences may also account for the paucity of eclogite in the early164 Earth geological record, with omphacite-absent garnet-clinopyroxenite shown to be stable at 165 high- $P$ conditions instead (Fig. 2a-b). Consequently, the application of modern-day 166 classification systems ${ }^{5,6}$ to identification of ancient subduction-zone metamorphism is 167 untenable in a natural system that is strongly asymmetric, as they are dependent upon low$168 \mathrm{MgO}$ modern MOR basalt compositions. Feldspar-absent, Na-rich actinolite- and chlorite169 dominated rocks that may have previously been interpreted as having formed at lower- $P$ 170 greenschist-facies crustal conditions offer important opportunity for re-examination in the 171 search for petrological evidence of ancient subduction. 
174 1. Maruyama, S., Liou, J.G., \& Terabayashi, M. Blueschists and eclogites of the world and 175 their exhumation. Int. Geol. Rev. 38, 485-594 (1996).

176 2. Turner, S., Rushmer, T., Reagan, M., \& Moyen, J.F. Heading down early on? Start of 177 subduction on Earth. Geology 42, 139-142 (2014).

178 3. Syracuse, E.M., van Keken, P.E. \& Abers, G.A. The global range of subduction zone 179 thermal models. Phys. Earth Planet. In. 183, 73-90 (2010).

180 4. Herzberg, C., Condie, K. \& Korenaga, J. Thermal history of the Earth and its petrological 181 expression. Earth Planet. Sci. Lett. 292, 79-88 (2010).

182 5. Bailey, E.H. Metamorphic facies of the Franciscan formation of California and their 183 geologic significance. Geol. S. Am. S. 68, 4-5 (1961).

184 6. Ernst, W.G. Petrogenesis of glaucophane schists. J. Petrol. 4, 1-30 (1963).

185 7. Stern, R.J. Evidence from ophiolites, blueschists, and ultrahigh-pressure metamorphic 186 terranes that the modern episode of subduction tectonics began in Neoproterozoic time. 187 Geology 33, 557-560 (2005).

188 8. Hamilton, W.B. Plate tectonics began in Neoproterozoic time, and plumes from the deep 189 mantle have never operated. Lithos 123, 1-20 (2011).

190 9. Shirey, S.B. \& Richardson, S.H. Start of the Wilson Cycle at 3 Ga shown by diamonds 191 from subcontinental mantle. Science 333, 434-436 (2011).

192 10. Furnes, H., de Wit, M., Staudigel, H., Rosing, M. \& Muehlenbachs, K. A vestige of 193 Earth's oldest ophiolite. Science 315, 1704-1707 (2007).

194 11. Martin, H. \& Moyen, J.F. Secular changes in tonalite-trondhjemite-granodiorite 195 composition as markers of the progressive cooling of Earth. Geology 30, 319-322 (2002).

196 12. Kirby, S.H., Durham, W.B. \& Stern, L.A. Mantle phase changes and deep-earthquake 197 faulting in subducting lithosphere. Science 252, 216-225 (1991). 
198 13. Peacock, S.M. Thermal and petrologic structure of subduction zones. In Bebout, G.E., et

199 al., eds., Subduction: Top to Bottom. Geophysical Monograph of the American

$200 \quad$ Geophysical Union 96, 119-133 (1996).

201 14. Hargraves, R.B. Faster spreading or greater ridge length in the Archean? Geology 14, $202 \quad 750-752(1986)$.

203 15. Foley, S.F., Buhre, S. \& Jacob, D.E. Evolution of the Archean crust by delamination and 204 shallow subduction. Nature 421, 249-252 (2003).

205 16. Furnes, H., Dilek, Y. \& de Wit, M. Precambrian greenstone sequences represent different 206 ophiolite types. Gondwana Res. 27, 649-685 (2014).

207 17. Ziaja, K., Foley, S.F., White, R.W. \& Buhre, S. Metamorphism and melting of picritic 208 crust in the early Earth. Lithos 189, 173-184 (2014).

209 18. Clarke, G.L., Powell, R. \& Fitzherbert, J.A. The lawsonite paradox: a comparison of field 210 evidence and mineral equilibria modelling. J. Met. Geol. 24, 715-725 (2006).

211 19. Brown, M. Duality of thermal regimes is the distinctive characteristic of plate tectonics 212 since the Neoarchean. Geology 34, 961-964 (2006).

213 20. Griffin, W.L., et al. The origin and evolution of Archean lithospheric mantle. 214 Precambrian Res. 127, 19-41 (2003).

215 21. Warren, C.J., Beaumont, C. \& Jamieson, R.A. Modelling tectonic styles and ultra-high 216 pressure (UHP) rock exhumation during the transition from oceanic subduction to 217 continental collision. Earth Planet. Sci. Lett. 267, 129-45 (2008).

218 22. Korenaga, J. Initiation and evolution of plate tectonics on Earth: Theories and 219 observations. Annu. Rev. Earth Sci. 41, 117-51 (2013).

220 23. Husson, L., Brun, J.P., Yamato, P. \& Faccenna, C. Episodic slab rollback fosters 221 exhumation of HP-UHP rocks. Geophys. J. Int. 179, 1292-1300 (2009). 
24. St-Onge, M.R., Rayner, N., Palin, R.M., Searle, M.P. \& Waters, D.J. Integrated pressuretemperature-time constraints for the Tso Morari dome (Northwest India): implications for the burial and exhumation path of UHP units in the western Himalaya. J. Metamorph. Geol. 31, 469-504 (2013).

25. Whitney, D.L. \& Davis, P.B. Why is lawsonite eclogite so rare? Metamorphism and preservation of lawsonite eclogite, Sivrihisar, Turkey. Geology 34, 473-476 (2006).

26. van Keken, P.E., Hacker, B.R., Syracuse, E.M. \& Abers, G.A. Subduction factory: 4. Depth-dependent flux of $\mathrm{H}_{2} \mathrm{O}$ from subducting slabs worldwide. J. Geophys. Res. 116, B01401 (2011).

27. Grove, T.L., Till, C.B., Lev, E., Chatterjee, N. \& Médard, E. Kinematic variables and water transport control the formation and location of arc volcanoes. Nature 459, 694-697 (2009).

28. Schmidt, M.W. \& Poli, S. Experimentally based water budgets for dehydrating slabs and consequences for arc magma generation. Earth Planet. Sci. Lett. 163, 361-379 (1998).

\section{Acknowledgements}

Comments from B. Kaus and J. Castro (JGU Mainz) are gratefully appreciated. R. Powell (Uni. Melbourne) is thanked for providing code to calculate densities with THERMOCALC.

\section{Author contributions}

R.M.P. conceived the idea and performed the calculations. Both authors analysed the data and wrote the paper.

\section{Competing financial interests}

The authors declare no competing financial interests. 
248 Figure captions

249 Figure 1 Results of phase equilibria modelling calculations. a, Palaeoarchean high-MgO

250 basalt; b, Palaeoproterozoic olivine-bearing basalt; c, Mesoproterozoic gabbro; and d,

251 Neoproterozoic pillow basalt. Rock types are defined by assemblages listed in the Methods

252 section. Stippled regions mark glaucophane stability. Phase diagrams showing full mineral

253 assemblages calculated for each rock type are shown in Fig. S1. Actinolite differs from

254 tremolite by having molar $\mathrm{Mg} /(\mathrm{Mg}+\mathrm{Fe})<0.9$, and from winchite by having molar

$255 \mathrm{Na} /(\mathrm{Na}+\mathrm{Ca})<0.25$ in the M4 crystallographic site. Isobaric profile lines at $0.6 \mathrm{GPa}$ mark the

256 greenschist-facies conditions over which actinolite compositional data shown in Fig. S3 were

257 calculated.

259 Figure 2 Modebox plots of changes in calculated mineral proportions and bulk-rock density

260 during metamorphism along a warm geotherm $\left(350^{\circ} \mathrm{C} / \mathrm{GPa}\right)$. a, Palaeoarchean high-MgO

261 basalt; b, Palaeoproterozoic olivine-bearing basalt; c, Mesoproterozoic gabbro; and d,

262 Neoproterozoic pillow basalt. Bulk-rock densities $\left(\mathrm{g} / \mathrm{cm}^{3}\right)$ for each sample are represented by

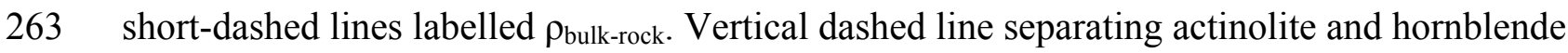

264 in part $\mathbf{c}$ represents the position of their solvus at the pressure-temperature conditions of

265 interest.

267 Figure 3 Schematic diagrams showing the different petrological evolutions of a, high-MgO

268 Archean and b, low-MgO Neoproterozoic-modern-day oceanic crust. Isotherms are

269 qualitative and positioned in order to define a warm geotherm of $350{ }^{\circ} \mathrm{C} / \mathrm{GPa}$ along the

270 descending slab surface. Oceanic crust is represented as being $\sim 25-30 \mathrm{~km}$ thick in the

271 Archean $^{14}$ and $7 \mathrm{~km}$ thick in the Phanerozoic ${ }^{4}$, although only the uppermost $5 \mathrm{~km}$ is assumed 
272 to be hydrated ${ }^{28}$ in each case. Insets show the molar percentage of $\mathrm{H}_{2} \mathrm{O}$ released from hydrous 273 phases during subduction (cf. Fig. S4).

275 Methods

276 Phase equilibria modelling was performed in the 10-component NCKFMASHTO $\left(\mathrm{Na}_{2} \mathrm{O}-\right.$

$277 \mathrm{CaO}-\mathrm{K}_{2} \mathrm{O}-\mathrm{FeO}-\mathrm{MgO}-\mathrm{Al}_{2} \mathrm{O}_{3}-\mathrm{SiO}_{2}-\mathrm{H}_{2} \mathrm{O}-\mathrm{TiO}_{2}-\mathrm{O}_{2}$ ) chemical system using THERMOCALC

278 version $3.40^{29}$ and the internally consistent thermodynamic dataset ds- $55^{30}$ (updated August

279 2004). A list of model parameters, activity-composition relationships for solid-solution

280 phases, and bulk-rock compositions utilised for modelling are given in the Supplementary

281 Information and Table S2. Rock types shown in Fig. 1 were defined according to the

282 equilibrium (minimum Gibbs free energy) mineral assemblages calculated via modelling. The

283 following mineral associations represent necessary constituents for each rock type:

284 Actinolite-chlorite-lawsonite-pyroxenite $=$ actinolite + chlorite + lawsonite +

285 diopside/omphacite; Actinolite-chlorite-epidote-pyroxenite $=$ actinolite + chlorite + epidote

286 + diopside/omphacite; Epidote-blueschist = epidote + glaucophane (no lawsonite); Lawsonite-

287 blueschist $=$ lawsonite + glaucophane; Greenschist $=$ albite + chlorite + actinolite ; Epidote-

288 amphibolite $=$ epidote + hornblende + plagioclase; Epidote-hornblendeite $=$ epidote +

289 hornblende (no plagioclase); Hornblendite = hornblende (no plagioclase or epidote);

290 Amphibolite $=$ hornblende + plagioclase $($ no epidote) ; Garnet-hornblendeite $=$ garnet +

291 hornblende/actinolite (no plagioclase); Garnet-pyroxenite $=$ garnet + diopside $($ no

292 plagioclase); Eclogite $=$ garnet + omphacite (no plagioclase). Note that discrimination

293 between eclogite and garnet-pyroxenite is determined by the composition of clinopyroxene,

294 with a sodic-calcic pyroxene (omphacite) a necessary constituent in the former, and a calcic

295 pyroxene necessary in the latter. 
296 Code availability: the software and datafiles used to generate the phase diagrams presented

297 herein can be downloaded at http://www.metamorph.geo.uni-mainz.de/thermocalc/

298

299 References only in methods

300 29. Powell, R. \& Holland, T.J.B. An internally consistent thermodynamic dataset with

301 uncertainties and correlations: 3. Application to geobarometry, worked examples, and a

302 computer program. J. Metamorp. Geol. 6, 173-204 (1988).

303 30. Holland, T.J.B. \& Powell, R. An internally consistent thermodynamic dataset for phases

304 of petrological interest. J. Metamorp. Geol. 16, 309-344 (1998). 
Figure 1

a

Palaeoarchean high-MgO basalt

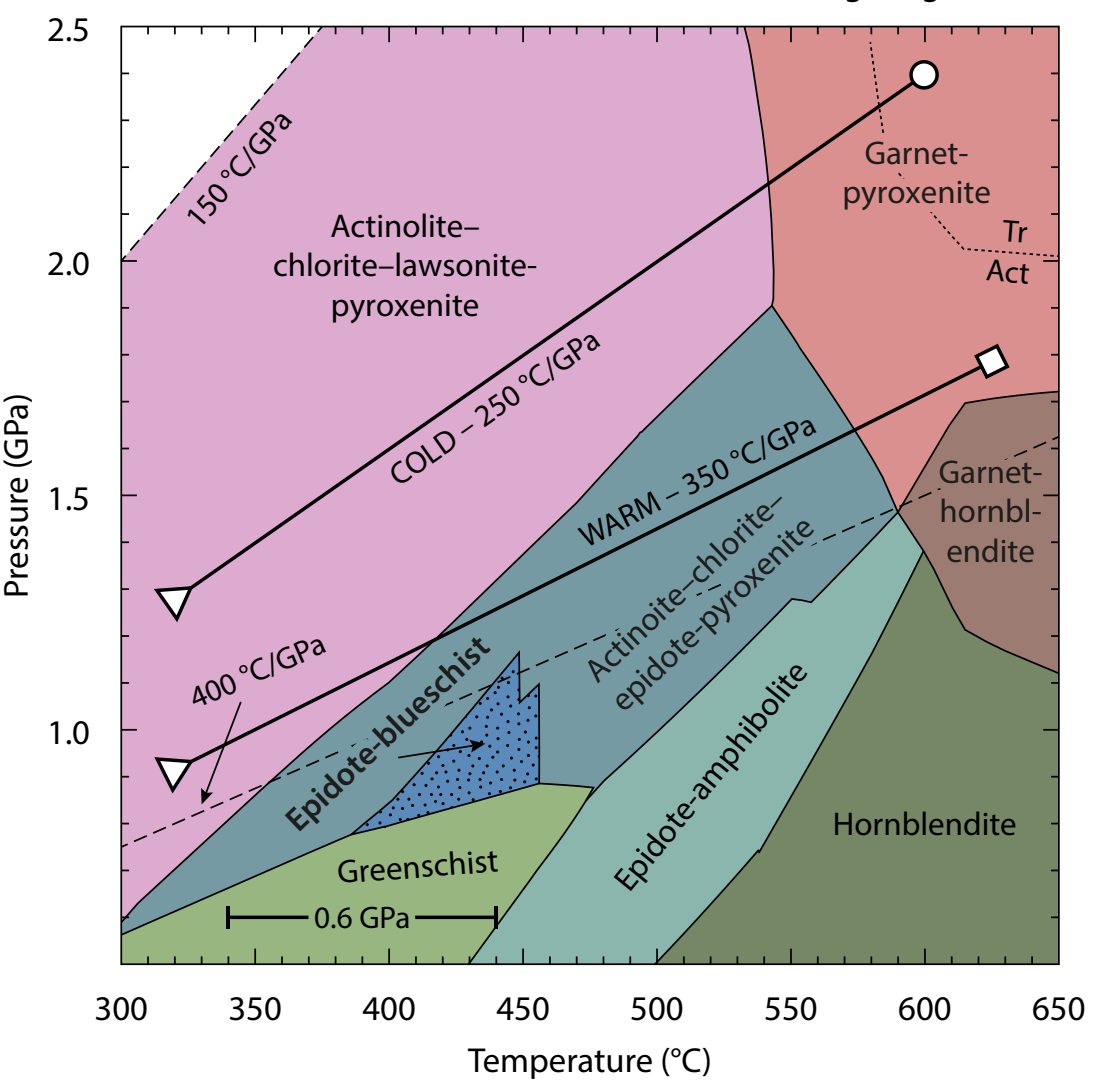

C

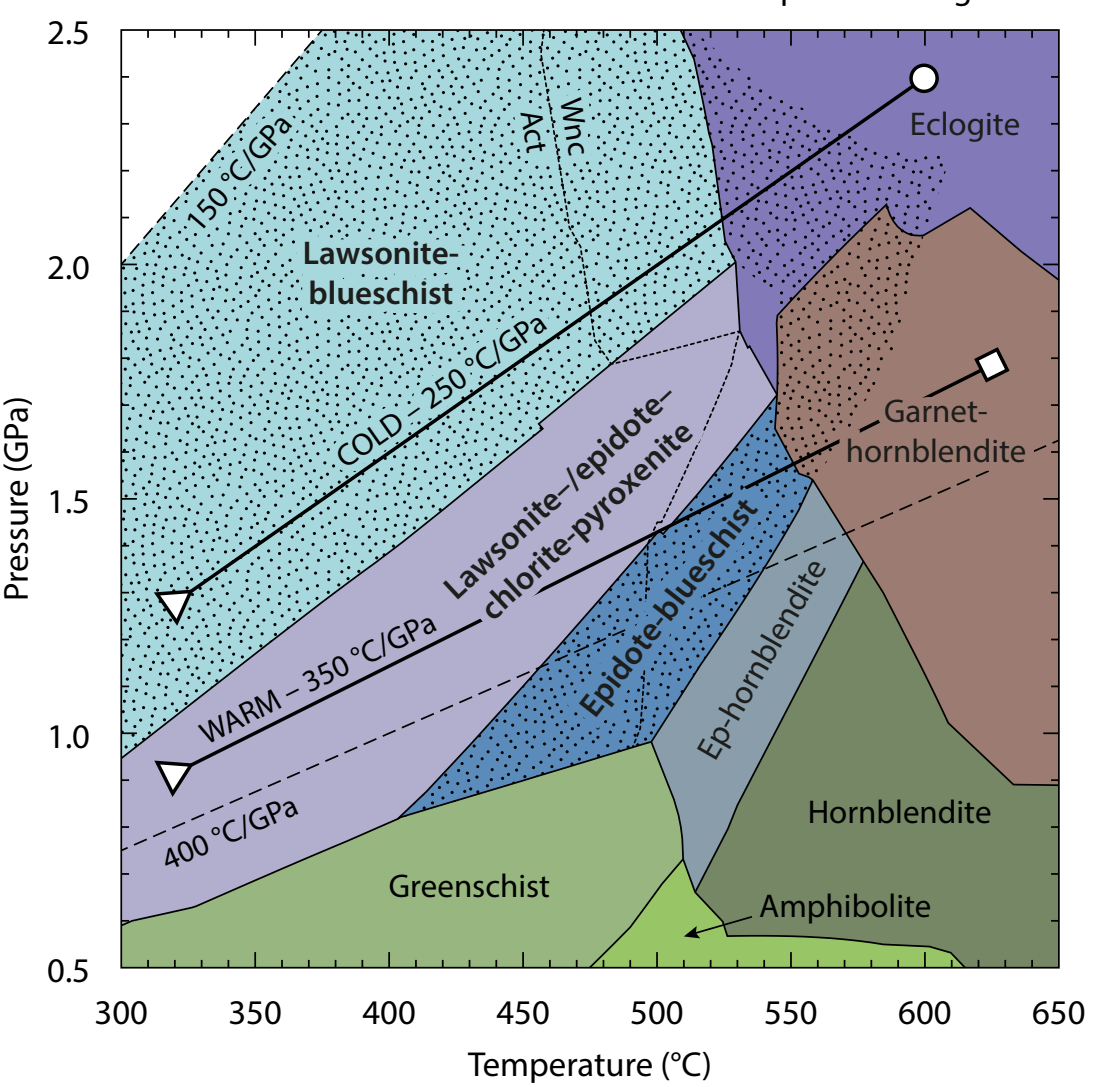

b

Palaeoproterozoic olivine-bearing basalt

2.5

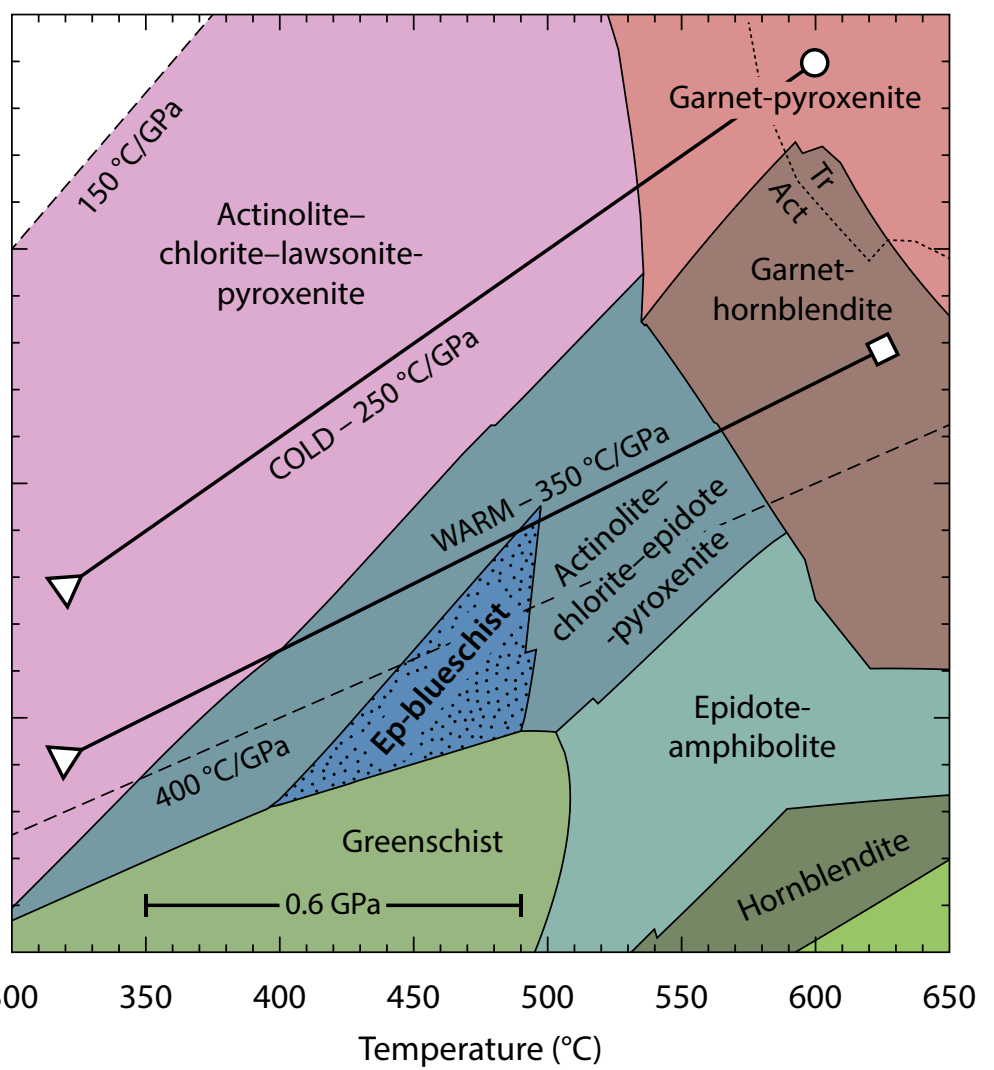

d

Neoproterozoic pillow basalt

2.5

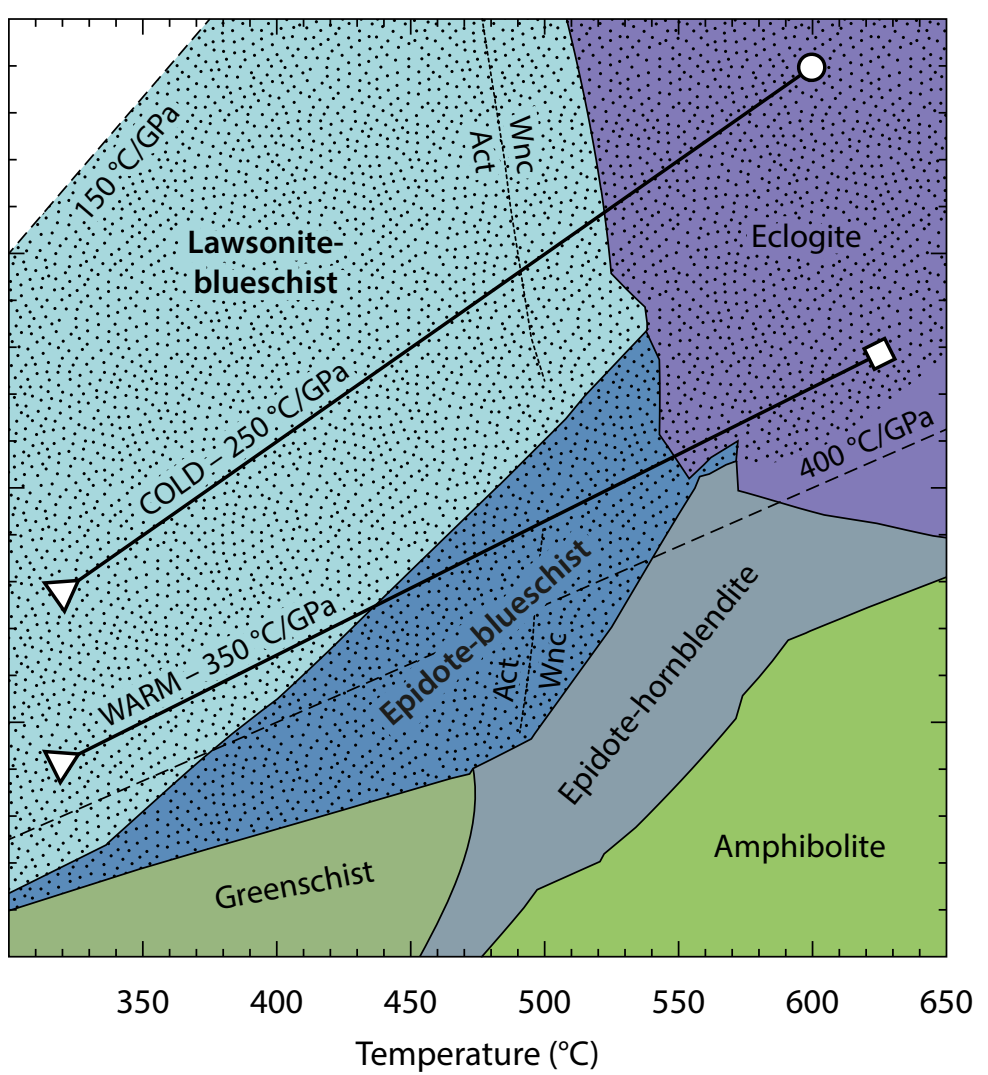




\section{Figure 2}

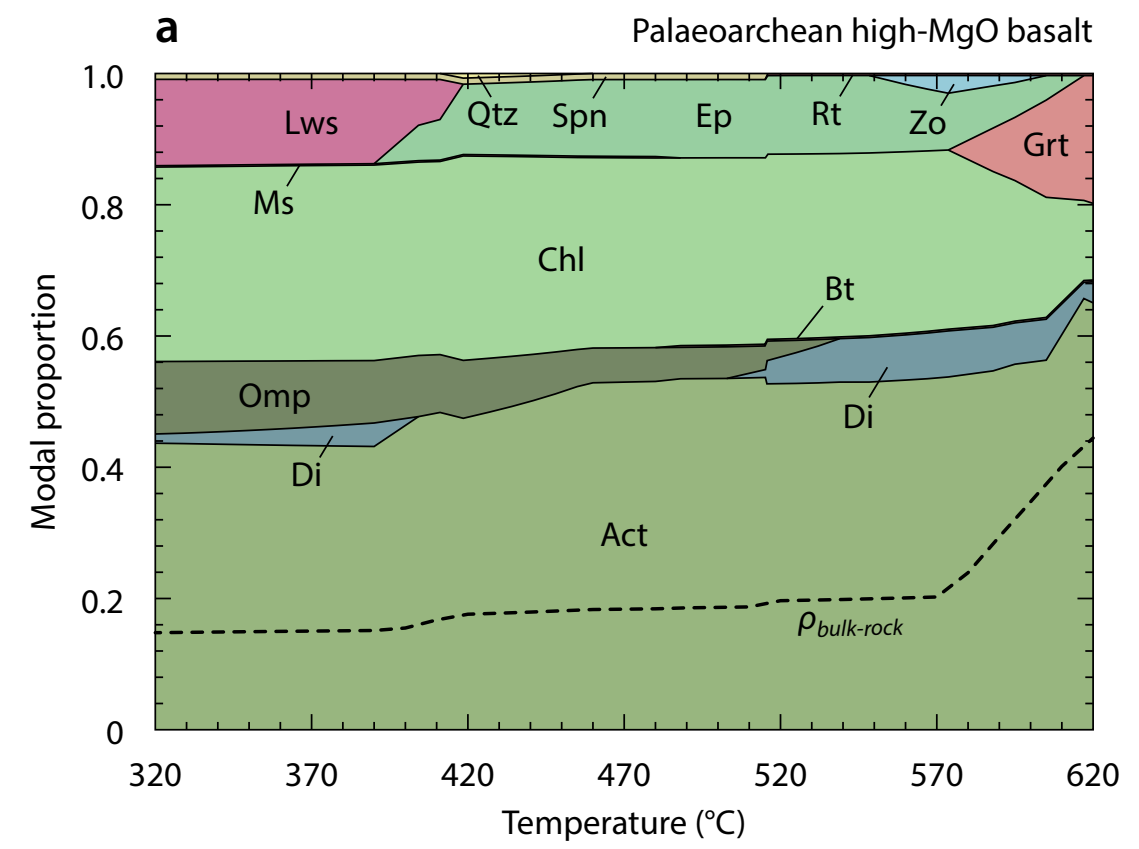

b

Palaeoproterozoic olivine-bearing basalt
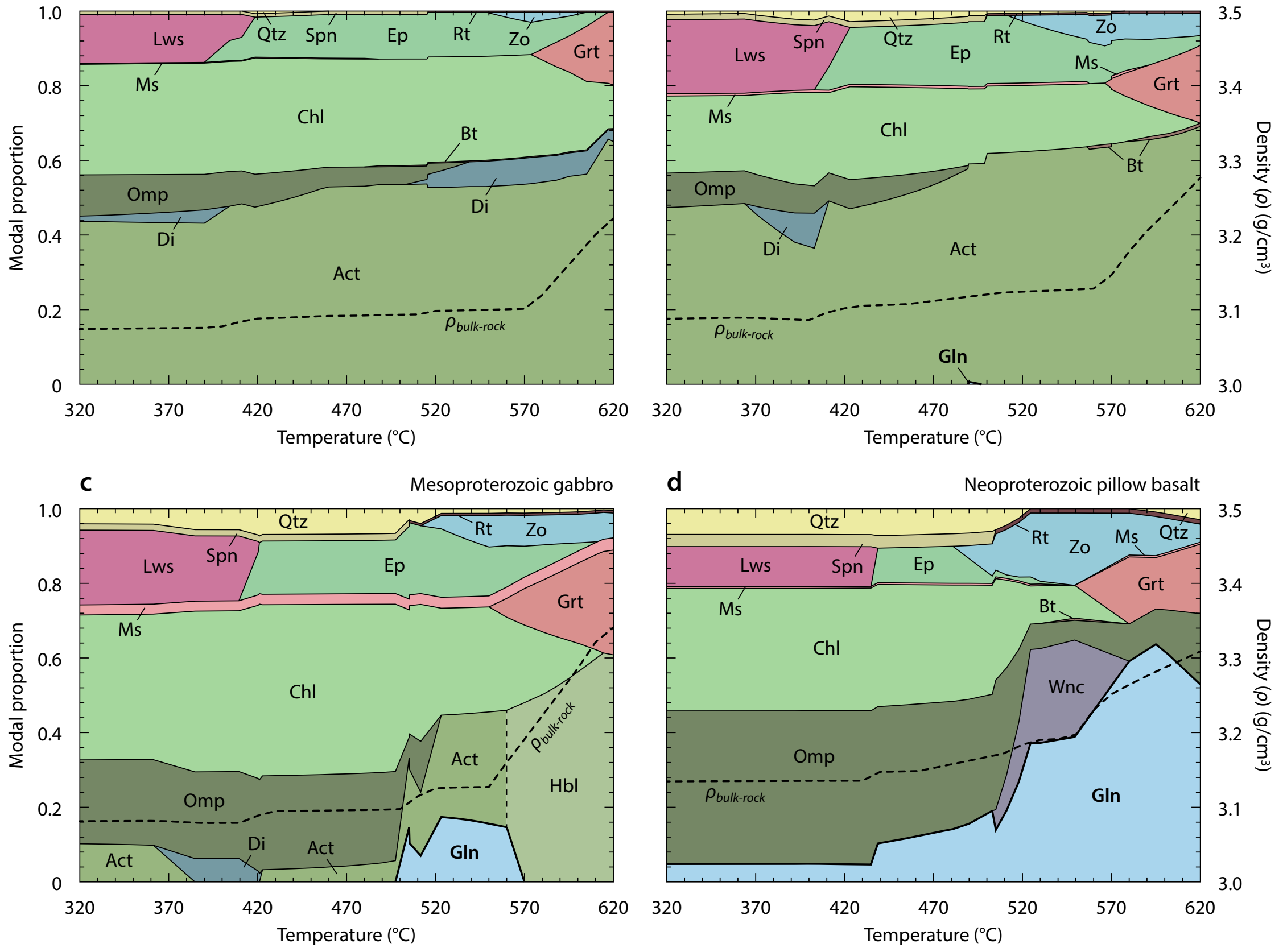
Figure 3

\section{a}

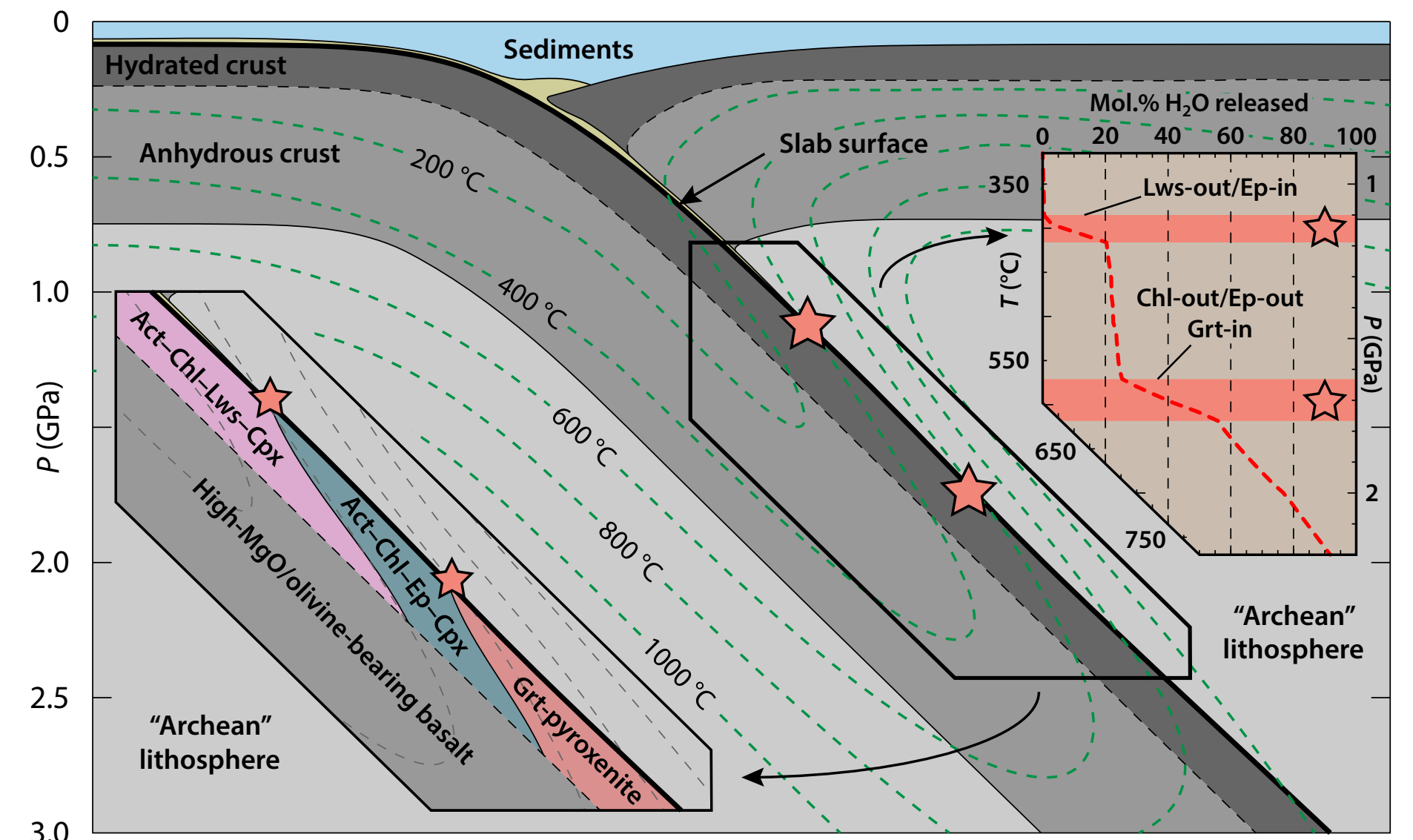

b

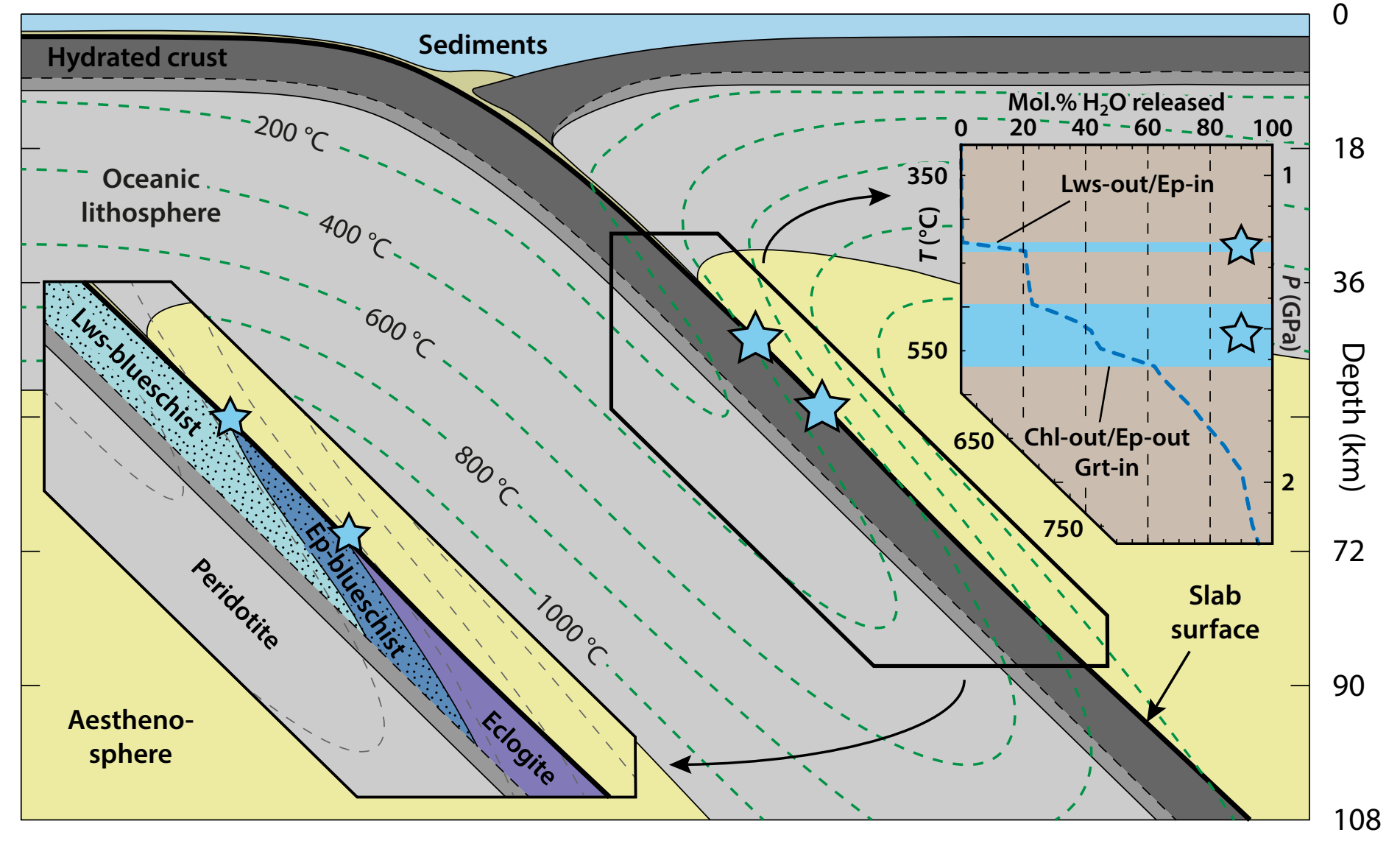




\title{
Emergence of blueschists on Earth linked to secular changes in oceanic crust composition
}

\author{
Richard M. Palin* and Richard W. White \\ Institute of Geosciences, Johannes-Gutenberg University Mainz, 55128 Mainz, Germany \\ * corresponding author: richardmpalin@gmail.com
}

Contents:

Early-Earth plate velocities and subduction geotherms

Sample selection methodology

Phase equilibria modelling procedures

Tables S1-S3

Figures S1-S4

References

\section{Early-Earth plate velocities and subduction geotherms}

Early studies of Archean geodynamics initially favoured the idea that plate tectonics operated at a significantly faster rate than on the present-day Earth, purportedly owing to the dissipation of internal heat from a significantly hotter mantle being most efficient in a scenario involving rapid sea-floor spreading and subduction of relatively young (20-30 Myr) crust (e.g. Bickle, 1978; Abbott \& Hoffman, 1984). Spreading rates up to $\sim 40 \mathrm{~cm} / \mathrm{yr}$ have been proposed (Dewey \& Windley, 1981; Nisbet \& Fowler, 1983): notably faster than the typical present-day range of 1-10 $\mathrm{cm} / \mathrm{yr}$ (Solomon et al., 1975). Though some workers continue to support this 'fast-plate' hypothesis (van Krankendonk \& Kirkland, 2013), the general consensus in the geological community today appears to be that plate velocities in the deep geological past were relatively more sluggish than today, though they "should not differ greatly from that at the present" (Korenaga, 2013). Such interpretations have been made on the basis of geological observations, with passive margins interpreted to have had longer lifespans in the Precambrian than in the Phanerozoic (Bradley, 2008), palaeomagnetic and palaeogeographic data (Condie et al., 2015), the geochemical budget of radiogenic isotope exchange between the atmosphere and Earth interior (Padhi et al., 2012), and theoretical calculations providing constraints on the evolution of the Urey ratio over time (Korenaga, 2008; Herzberg et al., 2010).

Korenaga (2006) used secular changes in mantle heat flux to predict changes in plate velocity over time, scaled against an average present-day value of $4 \mathrm{~cm} / \mathrm{yr}$. Extrapolation back to the Proterozoic-Archean boundary produced a scaled plate velocity of $\sim 3 \mathrm{~cm} / \mathrm{yr}$, with $\sim 2 \mathrm{~cm} / \mathrm{yr}$ at the Archean-Hadean boundary. Linearly extrapolating these values against the $1-10 \mathrm{~cm} / \mathrm{yr}$ present-day total range (above) leads to the conclusion that Archean subduction may have occurred at rates of $\sim 0.5-7.5 \mathrm{~cm} / \mathrm{yr}$, with the crust being subducted having been commensurately 
older (and thus colder; Korenaga, 2013) than the $\sim 60$-Myr present-day average (Bickle, 1978). The effect that slower and older descending crust may have on subduction zone thermal structure can be interpreted on a first-order basis via comparison with present-day analogues that show similar physical parameters. Investigation of slab-top pressure-temperature profiles was performed via examination of the global database compiled by Syracuse et al. (2010). For subduction zones characterised by values similar to these average "Archean" parameters (e.g. the North and South Lesser Antilles; table 2 of Syracuse et al., 2010), temperatures along the subducting slab surfaces reach $\sim 950{ }^{\circ} \mathrm{C}$ at $2.5 \mathrm{GPa}$, but are typically lower $\left(\sim 700-800{ }^{\circ} \mathrm{C}\right.$; figs. 6 and 12 in Syracuse et al., 2010). These data define subduction geotherms of $\sim 280-380^{\circ} \mathrm{C} / \mathrm{GPa}$.

In conjunction with this comparative approach, we can also consider recently reported geological evidence for subduction geotherms in the early Earth. Moyen et al. (2006) and Ganne et al. (2011) identified petrological evidence in a series of high- $P$ metasediments for warm subduction in the early Earth along geotherms of $10-12{ }^{\circ} \mathrm{C} / \mathrm{km}$ - equivalent to $\sim 350-400$ ${ }^{\circ} \mathrm{C} / \mathrm{GPa}$. These data were obtained via combinations of conventional thermobarometry and phase equilibria modelling. Both studies interpreted such cool $P-T$ conditions as evidence of the operation of modern-day plate tectonics and blueschist-facies metamorphism in the Archean and Proterozoic (c. $3.2 \mathrm{Ga}$ and c. $2.15 \mathrm{Ga}$, respectively).

\section{Sample selection methodology}

The choice of samples employed in phase equilibria modelling was assisted by the Furnes et al. (2014) geochemical database of Precambrian greenstone belts, which utilised geochemical discrimination systematics of immobile elements (e.g. $\mathrm{Al}_{2} \mathrm{O}_{3}, \mathrm{TiO}_{2}, \mathrm{Zr}$ and $\mathrm{Ni}$ ) to classify 111 terranes distributed worldwide as having either plume, mid-ocean ridge (MOR), continental margin, volcanic arc, or suprasubduction zone affinity. In many cases, each terrane contained components showing affinities with multiple tectonic settings. Samples chosen for modelling in this work were selected based on having at least some MOR geochemical characteristics (see table 3 in Furnes et al., 2014), as such rocks are inferred to most closely reflect the evolving composition of the primitive crust throughout Earth history: a predicted consequence of secular cooling of the mantle since the Archean (cf. Herzberg et al., 2010 and see main text). Specific samples from each study were then selected based on the reported degree of alteration and/or metamorphism. Those reported to contain original igneous microstructures, macrostructures, and/or mineralogies were preferentially selected.

\section{Phase equilibria modelling procedures}

\section{Pressure-temperature diagrams}

Pseudosections were constructed using THERMOCALC v3.40 with the internally consistent thermodynamic data set ds55 (Powell and Holland, 1988; Holland and Powell, 1998; updated to August 2004). Modelling was performed in the 10 -component $\mathrm{Na}_{2} \mathrm{O}-\mathrm{CaO}-\mathrm{K}_{2} \mathrm{O}-\mathrm{FeO}-\mathrm{MgO}-$ $\mathrm{Al}_{2} \mathrm{O}_{3}-\mathrm{SiO}_{2}-\mathrm{H}_{2} \mathrm{O}-\mathrm{TiO}_{2}-\mathrm{O}_{2}$ (NCKFMASHTO) compositional system using the following activity-composition relations for solid-solution phases: glaucophane, actinolite, hornblende, cummingtonite, diopside, omphacite, and jadeite (Diener and Powell, 2012), muscovite and paragonite (Coggon and Holland, 2002), talc and epidote (Holland and Powell, 1998), chlorite (Holland et al., 1998), biotite and garnet (White et al., 2007), plagioclase and K-feldspar (Holland 
and Powell, 2003), ilmenite (White et al., 2000). Pure phases included albite, zoisite, lawsonite, pumpellyite, rutile, sphene, quartz, kyanite, and $\mathrm{H}_{2} \mathrm{O}$. The bulk-rock compositions used for modelling were converted from weight $\%$ oxides, as reported in each original study (Table S1), to molar \% oxides (Table S2). Fluid was considered to be an excess phase in all cases, owing to the observations outlined by Schmidt \& Poli (1998) (and references therein) that hydrated metabasites contain approximately $5-6 \mathrm{wt} \% \mathrm{H}_{2} \mathrm{O}$ in the lower blueschist facies. Oxygen isotope analyses from 4.4-4.0 Ga zircons infer the existence of surface water on the early Earth (Peck et al., 2001), allowing for the interpretation that hydration of Archean oceanic crust occurred in a similar manner to that documented today. Mixed component fluids were not considered due to the lack of suitable activity models describing their behaviour at the high- $P /$ low $-T$ conditions under investigation. For internal consistency and ease of comparison, all calculations used a constant molar bulk-rock $\mathrm{Fe}_{2} \mathrm{O}_{3} /\left(\mathrm{Fe}_{2} \mathrm{O}_{3}+\mathrm{FeO}\right)$ value of 0.1 (cf. Christie et al., 1986; Berry et al., 2008). Mineral abbreviations are after Kretz (1983). Pressure uncertainties for assemblage field boundaries are approximately \pm 1 kbar at the $2 \sigma$ level (Powell \& Holland, 2008; Palin et al., 2015).

\section{$\mathrm{H}_{2} \mathrm{O}$-content diagram (Fig. S4)}

The relative proportion of $\mathrm{H}_{2} \mathrm{O}$ calculated to occur structurally bound within hydrous phases and as a free fluid along a warm geotherm was determined by setting water as a non-excess phase for each sample and determining the molar proportion required to achieve minimal fluid saturation at $320{ }^{\circ} \mathrm{C}$. These values were $14.53 \mathrm{~mol}$. \% (4.90 wt\%) for the S01 Neoproterozoic pillow basalt bulk composition and $16.31 \mathrm{~mol}$. \% (5.93 wt\%) for the KN03 high-MgO basalt bulk composition. Both water contents lie within the typical range suggested for lower blueschist-facies hydrated oceanic crust (Schmidt \& Poli, 1998). Equilibrium assemblages were then calculated along the $350{ }^{\circ} \mathrm{C} / \mathrm{GPa}$ geotherm, which allowed determination of the proportion of water present as a free fluid phase and thus calculation of the percentage of structurally bound $\mathrm{H}_{2} \mathrm{O}$ released during metamorphism. 
Table S1 Bulk-rock compositions of mafic crustal components discussed in this work (weight \% oxides).

\begin{tabular}{lcccccccccc}
\hline Lithology & Reported age (Ma) & $\mathrm{SiO}_{2}$ & $\mathrm{TiO}_{2}$ & $\mathrm{Al}_{2} \mathrm{O}_{3}$ & $\mathrm{Fe}_{2} \mathrm{O}_{3}$ & $\mathrm{FeO}$ & $\mathrm{MgO}$ & $\mathrm{CaO}$ & $\mathrm{Na}_{2} \mathrm{O}$ & $\mathrm{K}_{2} \mathrm{O}$ \\
\hline High-MgO basalt $^{1}$ & c. 3450 (Palaeoarchean) & 48.75 & 0.48 & 10.32 & 1.21 & 9.81 & 16.19 & 10.49 & 1.42 & 0.03 \\
Olivine-bearing basalt $^{2}$ & c. 1870 (Palaeoproterozoic) & 49.96 & 0.79 & 11.00 & 1.10 & 8.88 & 14.07 & 11.57 & 1.30 & 0.09 \\
Gabbro $^{3}$ & c. 1300 (Mesoproterozoic) & 46.40 & 0.88 & 15.70 & 1.30 & 10.50 & 11.20 & 9.13 & 1.92 & 0.38 \\
Pillow basalt $^{4}$ & c. 563 (Neoproterozoic) & 50.33 & 1.61 & 13.49 & 1.12 & 9.05 & 9.66 & 9.22 & 3.59 & 0.06 \\
Modern MORB $^{5}$ & c. 0-200 Ma (Phanerozoic) & 50.89 & 1.73 & 14.47 & 1.08 & 8.75 & 8.00 & 10.95 & 2.78 & 0.16 \\
\hline
\end{tabular}

N.B. $\mathrm{Fe}_{2} \mathrm{O}_{3}$ contents were calculated assuming a bulk-rock $\mathrm{Fe}_{2} \mathrm{O}_{3} /\left(\mathrm{FeO}+\mathrm{Fe}_{2} \mathrm{O}_{3}\right)=0.1$. ${ }^{1}$ Kato and Nakamura (2003), sample 02MB256; ${ }^{2} \mathrm{Hynes}$ and Francis (1982), sample CHK-MGO14; ${ }^{3}$ Condie and Myers (1999), sample 769; ${ }^{4}$ Savov et al. (2001), sample BA-23; ${ }^{5}$ Albarède (2005), average of $\sim 5,000$ mid-ocean ridge basalt glass analyses.

Table S2 Bulk-rock compositions utilised in phase equilibria modelling (molar \% oxides). See Table S1 for original data sources.

\begin{tabular}{|c|c|c|c|c|c|c|c|c|c|c|c|}
\hline Lithology & Figures & $\mathrm{H}_{2} \mathrm{O}$ & $\mathrm{SiO}_{2}$ & $\mathrm{Al}_{2} \mathrm{O}_{3}$ & $\mathrm{CaO}$ & $\mathrm{MgO}$ & $\mathrm{FeO}$ & $\mathrm{K}_{2} \mathrm{O}$ & $\mathrm{Na}_{2} \mathrm{O}$ & $\mathrm{TiO}_{2}$ & $\mathrm{O}$ \\
\hline \multirow[t]{2}{*}{ High-MgO basalt } & 1a, 2a, 3a, S1a, S2a, S3 & excess & 48.02 & 5.99 & 11.07 & 23.77 & 8.98 & 0.02 & 1.36 & 0.36 & 0.45 \\
\hline & S4 & 16.32 & 40.18 & 5.01 & 9.26 & 19.89 & 7.51 & 0.02 & 1.14 & 0.30 & 0.38 \\
\hline Olivine-bearing basalt & $1 b, 2 b, S 1 b, S 2 b, S 3$ & excess & 49.77 & 6.46 & 12.35 & 20.89 & 8.22 & 0.06 & 1.26 & 0.59 & 0.41 \\
\hline Gabbro & $1 \mathrm{c}, 2 \mathrm{c}, \mathrm{S} 1 \mathrm{c}, \mathrm{S} 2 \mathrm{c}$ & excess & 48.77 & 9.72 & 10.28 & 17.55 & 10.26 & 0.26 & 1.96 & 0.70 & 0.51 \\
\hline \multirow[t]{2}{*}{ Pillow basalt } & $1 d, 2 d, 3 b, S 1 d, S 2 d$ & excess & 52.37 & 8.27 & 10.28 & 14.98 & 8.75 & 0.04 & 3.62 & 1.26 & 0.44 \\
\hline & S4 & 14.53 & 44.76 & 7.07 & 8.79 & 12.80 & 7.48 & 0.03 & 3.10 & 1.08 & 0.37 \\
\hline
\end{tabular}


Table S3 Representative compositions of actinolite calculated along various geotherms for Palaeoarchean high-MgO basalt (KN03) and Palaeoproterozoic olivine-bearing basalt (HF82) bulk-rock compositions.

\begin{tabular}{|c|c|c|c|c|c|c|c|c|c|c|c|c|c|}
\hline \multirow{2}{*}{\multicolumn{2}{|c|}{ Temp. $\left({ }^{\circ} \mathrm{C}\right)$}} & \multicolumn{4}{|c|}{ KN03 cold $\left(250{ }^{\circ} \mathrm{C} / \mathrm{GPa}\right)$ geotherm } & \multicolumn{4}{|c|}{ KN03 warm $\left(350^{\circ} \mathrm{C} / \mathrm{GPa}\right)$ geotherm } & \multicolumn{4}{|c|}{ KN03 greenschist (0.6 GPa profile) } \\
\hline & & 340 & 370 & 400 & 440 & 340 & 370 & 400 & 440 & 340 & 370 & 400 & 440 \\
\hline & $\mathrm{Si}$ & 8.000 & 8.000 & 8.000 & 8.000 & 8.000 & 8.000 & 8.000 & 8.000 & 8.000 & 7.999 & 7.996 & 7.935 \\
\hline & Al & 0.081 & 0.100 & 0.123 & 0.159 & 0.088 & 0.108 & 0.147 & 0.217 & 0.092 & 0.102 & 0.115 & 0.209 \\
\hline & $\mathrm{Fe}^{3+}$ & 0.060 & 0.072 & 0.084 & 0.100 & 0.061 & 0.071 & 0.067 & 0.067 & 0.045 & 0.048 & 0.051 & 0.066 \\
\hline & $\mathrm{Fe}^{2+}$ & 0.914 & 0.897 & 0.893 & 0.887 & 0.950 & 0.947 & 0.955 & 0.952 & 1.012 & 1.023 & 1.034 & 1.053 \\
\hline & $\mathrm{Mg}$ & 3.946 & 3.933 & 3.904 & 3.862 & 3.902 & 3.875 & 3.834 & 3.771 & 3.852 & 3.828 & 3.806 & 3.742 \\
\hline & $\mathrm{Ca}$ & 1.754 & 1.721 & 1.687 & 1.636 & 1.764 & 1.737 & 1.700 & 1.625 & 1.770 & 1.749 & 1.731 & 1.726 \\
\hline & $\mathrm{Na}$ & 0.348 & 0.381 & 0.411 & 0.451 & 0.321 & 0.343 & 0.380 & 0.456 & 0.323 & 0.352 & 0.377 & 0.397 \\
\hline & Sum & 15.103 & 15.104 & 15.102 & 15.096 & 15.086 & 15.081 & 15.083 & 15.087 & 15.093 & 15.102 & 15.110 & 15.126 \\
\hline & $X \mathrm{Mg}$ & 0.812 & 0.814 & 0.814 & 0.813 & 0.804 & 0.804 & 0.801 & 0.798 & 0.792 & 0.789 & 0.786 & 0.780 \\
\hline $\mathrm{T} 2$ & $\mathrm{Si}$ & 4.000 & 4.000 & 4.000 & 4.000 & 4.000 & 4.000 & 4.000 & 4.000 & 4.000 & 4.000 & 4.000 & 4.000 \\
\hline \multirow[t]{2}{*}{$\mathrm{T} 1$} & $\mathrm{Si}$ & 4.000 & 4.000 & 4.000 & 4.000 & 4.000 & 4.000 & 4.000 & 4.000 & 4.000 & 3.999 & 3.996 & 3.935 \\
\hline & ${ }^{\mathrm{IV}} \mathrm{Al}$ & 0.000 & 0.000 & 0.000 & 0.000 & 0.000 & 0.000 & 0.000 & 0.000 & 0.000 & 0.001 & 0.004 & 0.065 \\
\hline \multirow[t]{2}{*}{ M2 } & ${ }^{\mathrm{VI}} \mathrm{Al}$ & 0.081 & 0.100 & 0.123 & 0.159 & 0.088 & 0.108 & 0.147 & 0.216 & 0.091 & 0.101 & 0.110 & 0.144 \\
\hline & $\mathrm{Fe}^{3+}$ & 0.060 & 0.072 & 0.084 & 0.100 & 0.061 & 0.071 & 0.067 & 0.067 & 0.045 & 0.048 & 0.051 & 0.066 \\
\hline \multirow[t]{2}{*}{ (C site) } & $\mathrm{Fe}^{2+}$ & 0.349 & 0.339 & 0.334 & 0.325 & 0.363 & 0.357 & 0.356 & 0.346 & 0.388 & 0.390 & 0.393 & 0.393 \\
\hline & $\mathrm{Mg}$ & 1.509 & 1.489 & 1.459 & 1.415 & 1.489 & 1.463 & 1.430 & 1.371 & 1.476 & 1.460 & 1.446 & 1.397 \\
\hline $\mathrm{M} 1,3$ & $\mathrm{Fe}^{2+}$ & 0.564 & 0.557 & 0.558 & 0.561 & 0.588 & 0.589 & 0.598 & 0.605 & 0.624 & 0.633 & 0.641 & 0.659 \\
\hline \multirow{2}{*}{ (C site) } & $\mathrm{Mg}$ & 2.436 & 2.443 & 2.442 & 2.439 & 2.412 & 2.411 & 2.402 & 2.395 & 2.376 & 2.367 & 2.359 & 2.341 \\
\hline & $\mathrm{Ca}$ & 0.000 & 0.000 & 0.000 & 0.000 & 0.000 & 0.000 & 0.000 & 0.000 & 0.000 & 0.000 & 0.000 & 0.000 \\
\hline \multirow[t]{2}{*}{ M4 } & $\mathrm{Fe}^{2+}$ & 0.000 & 0.000 & 0.001 & 0.002 & 0.000 & 0.000 & 0.001 & 0.001 & 0.000 & 0.000 & 0.000 & 0.001 \\
\hline & $\mathrm{Mg}$ & 0.001 & 0.002 & 0.003 & 0.007 & 0.001 & 0.001 & 0.002 & 0.004 & 0.000 & 0.001 & 0.001 & 0.003 \\
\hline \multirow[t]{2}{*}{ (B site) } & $\mathrm{Ca}$ & 1.754 & 1.721 & 1.687 & 1.636 & 1.764 & 1.737 & 1.700 & 1.625 & 1.770 & 1.749 & 1.731 & 1.726 \\
\hline & $\mathrm{Na}$ & 0.245 & 0.277 & 0.309 & 0.355 & 0.235 & 0.261 & 0.297 & 0.369 & 0.230 & 0.251 & 0.267 & 0.271 \\
\hline \multirow[t]{2}{*}{ A site } & $\mathrm{Na}$ & 0.103 & 0.104 & 0.102 & 0.096 & 0.086 & 0.081 & 0.083 & 0.087 & 0.093 & 0.102 & 0.110 & 0.126 \\
\hline & vac & 0.897 & 0.896 & 0.898 & 0.904 & 0.914 & 0.919 & 0.917 & 0.913 & 0.907 & 0.898 & 0.890 & 0.874 \\
\hline
\end{tabular}


Table S3 (continued)

\begin{tabular}{|c|c|c|c|c|c|c|c|c|c|c|c|c|c|c|c|c|}
\hline & & \multicolumn{5}{|c|}{ HF82 cold $\left(250{ }^{\circ} \mathrm{C} / \mathrm{GPa}\right)$ geotherm } & \multicolumn{5}{|c|}{ HF82 warm $\left(350^{\circ} \mathrm{C} / \mathrm{GPa}\right)$ geotherm } & \multicolumn{5}{|c|}{ HF82 greenschist (0.6 GPa profile) } \\
\hline \multicolumn{2}{|c|}{ Temp. $\left({ }^{\circ} \mathrm{C}\right)$} & 350 & 380 & 410 & 440 & 490 & 350 & 380 & 410 & 440 & 490 & 350 & 380 & 410 & 440 & 490 \\
\hline & $\mathrm{Si}$ & 8.000 & 8.000 & 8.000 & 8.000 & 8.000 & 8.000 & 8.000 & 8.000 & 8.000 & 7.996 & 8.000 & 7.999 & 7.998 & 7.990 & 7.899 \\
\hline & $\mathrm{Al}$ & 0.122 & 0.131 & 0.139 & 0.156 & 0.208 & 0.099 & 0.116 & 0.159 & 0.219 & 0.332 & 0.095 & 0.103 & 0.113 & 0.131 & 0.272 \\
\hline & $\mathrm{Fe}^{3+}$ & 0.102 & 0.108 & 0.110 & 0.118 & 0.131 & 0.071 & 0.075 & 0.066 & 0.052 & 0.067 & 0.039 & 0.041 & 0.043 & 0.045 & 0.057 \\
\hline & $\mathrm{Fe}^{2+}$ & 1.027 & 1.026 & 1.023 & 1.020 & 1.011 & 1.049 & 1.017 & 1.033 & 1.013 & 1.042 & 1.092 & 1.101 & 1.109 & 1.117 & 1.133 \\
\hline & $\mathrm{Mg}$ & 3.751 & 3.739 & 3.734 & 3.716 & 3.674 & 3.782 & 3.794 & 3.746 & 3.722 & 3.577 & 3.775 & 3.757 & 3.740 & 3.721 & 3.653 \\
\hline & $\mathrm{Ca}$ & 1.671 & 1.660 & 1.651 & 1.628 & 1.554 & 1.747 & 1.727 & 1.690 & 1.638 & 1.504 & 1.786 & 1.781 & 1.777 & 1.773 & 1.780 \\
\hline & $\mathrm{Na}$ & 0.429 & 0.435 & 0.437 & 0.451 & 0.506 & 0.333 & 0.351 & 0.389 & 0.444 & 0.572 & 0.294 & 0.292 & 0.289 & 0.286 & 0.285 \\
\hline & Sum & 15.103 & 15.098 & 15.094 & 15.088 & 15.083 & 15.081 & 15.080 & 15.082 & 15.087 & 15.091 & 15.080 & 15.074 & 15.069 & 15.065 & 15.079 \\
\hline & $X \mathrm{Mg}$ & 0.785 & 0.785 & 0.785 & 0.785 & 0.784 & 0.783 & 0.789 & 0.784 & 0.786 & 0.774 & 0.776 & 0.773 & 0.771 & 0.769 & 0.763 \\
\hline $\mathrm{T} 2$ & $\mathrm{Si}$ & 4.000 & 4.000 & 4.000 & 4.000 & 4.000 & 4.000 & 4.000 & 4.000 & 4.000 & 4.000 & 4.000 & 4.000 & 4.000 & 4.000 & 4.000 \\
\hline \multirow[t]{2}{*}{ T1 } & $\mathrm{Si}$ & 4.000 & 4.000 & 4.000 & 4.000 & 4.000 & 4.000 & 4.000 & 4.000 & 4.000 & 3.996 & 4.000 & 3.999 & 3.998 & 3.990 & 3.899 \\
\hline & ${ }^{\mathrm{IV}} \mathrm{Al}$ & 0.000 & 0.000 & 0.000 & 0.000 & 0.000 & 0.000 & 0.000 & 0.000 & 0.000 & 0.004 & 0.000 & 0.001 & 0.002 & 0.010 & 0.101 \\
\hline \multirow[t]{2}{*}{ M2 } & ${ }^{\mathrm{VI}} \mathrm{Al}$ & 0.122 & 0.131 & 0.139 & 0.156 & 0.208 & 0.099 & 0.116 & 0.158 & 0.218 & 0.328 & 0.095 & 0.103 & 0.111 & 0.121 & 0.171 \\
\hline & $\mathrm{Fe}^{3+}$ & 0.102 & 0.108 & 0.110 & 0.118 & 0.131 & 0.071 & 0.075 & 0.066 & 0.052 & 0.067 & 0.039 & 0.041 & 0.043 & 0.045 & 0.057 \\
\hline \multirow[t]{2}{*}{ (C site) } & $\mathrm{Fe}^{2+}$ & 0.382 & 0.379 & 0.377 & 0.372 & 0.358 & 0.397 & 0.382 & 0.384 & 0.370 & 0.362 & 0.419 & 0.421 & 0.422 & 0.423 & 0.419 \\
\hline & $\mathrm{Mg}$ & 1.394 & 1.382 & 1.375 & 1.354 & 1.303 & 1.433 & 1.427 & 1.392 & 1.360 & 1.243 & 1.448 & 1.435 & 1.424 & 1.410 & 1.352 \\
\hline $\mathrm{M} 1,3$ & $\mathrm{Fe}^{2+}$ & 0.645 & 0.646 & 0.645 & 0.646 & 0.647 & 0.651 & 0.634 & 0.648 & 0.642 & 0.677 & 0.673 & 0.680 & 0.686 & 0.693 & 0.710 \\
\hline \multirow{2}{*}{ (C site) } & $\mathrm{Mg}$ & 2.355 & 2.354 & 2.355 & 2.354 & 2.353 & 2.349 & 2.366 & 2.352 & 2.358 & 2.323 & 2.327 & 2.320 & 2.314 & 2.307 & 2.290 \\
\hline & $\mathrm{Ca}$ & 0.000 & 0.000 & 0.000 & 0.000 & 0.000 & 0.000 & 0.000 & 0.000 & 0.000 & 0.000 & 0.000 & 0.000 & 0.000 & 0.000 & 0.000 \\
\hline \multirow[t]{2}{*}{ M4 } & $\mathrm{Fe}^{2+}$ & 0.000 & 0.001 & 0.001 & 0.002 & 0.005 & 0.000 & 0.000 & 0.001 & 0.001 & 0.003 & 0.000 & 0.000 & 0.001 & 0.001 & 0.003 \\
\hline & $\mathrm{Mg}$ & 0.001 & 0.003 & 0.005 & 0.008 & 0.018 & 0.001 & 0.001 & 0.003 & 0.004 & 0.011 & 0.001 & 0.001 & 0.002 & 0.004 & 0.011 \\
\hline \multirow[t]{2}{*}{ (B site) } & $\mathrm{Ca}$ & 1.671 & 1.660 & 1.651 & 1.628 & 1.554 & 1.747 & 1.727 & 1.690 & 1.638 & 1.504 & 1.786 & 1.781 & 1.777 & 1.773 & 1.780 \\
\hline & $\mathrm{Na}$ & 0.327 & 0.337 & 0.343 & 0.362 & 0.422 & 0.251 & 0.271 & 0.307 & 0.357 & 0.482 & 0.214 & 0.218 & 0.220 & 0.221 & 0.206 \\
\hline \multirow[t]{2}{*}{ A site } & $\mathrm{Na}$ & 0.103 & 0.098 & 0.094 & 0.088 & 0.083 & 0.081 & 0.080 & 0.082 & 0.087 & 0.091 & 0.080 & 0.074 & 0.069 & 0.065 & 0.079 \\
\hline & vac & 0.897 & 0.902 & 0.906 & 0.912 & 0.917 & 0.919 & 0.920 & 0.918 & 0.913 & 0.909 & 0.920 & 0.926 & 0.931 & 0.935 & 0.921 \\
\hline
\end{tabular}


Figure S1a

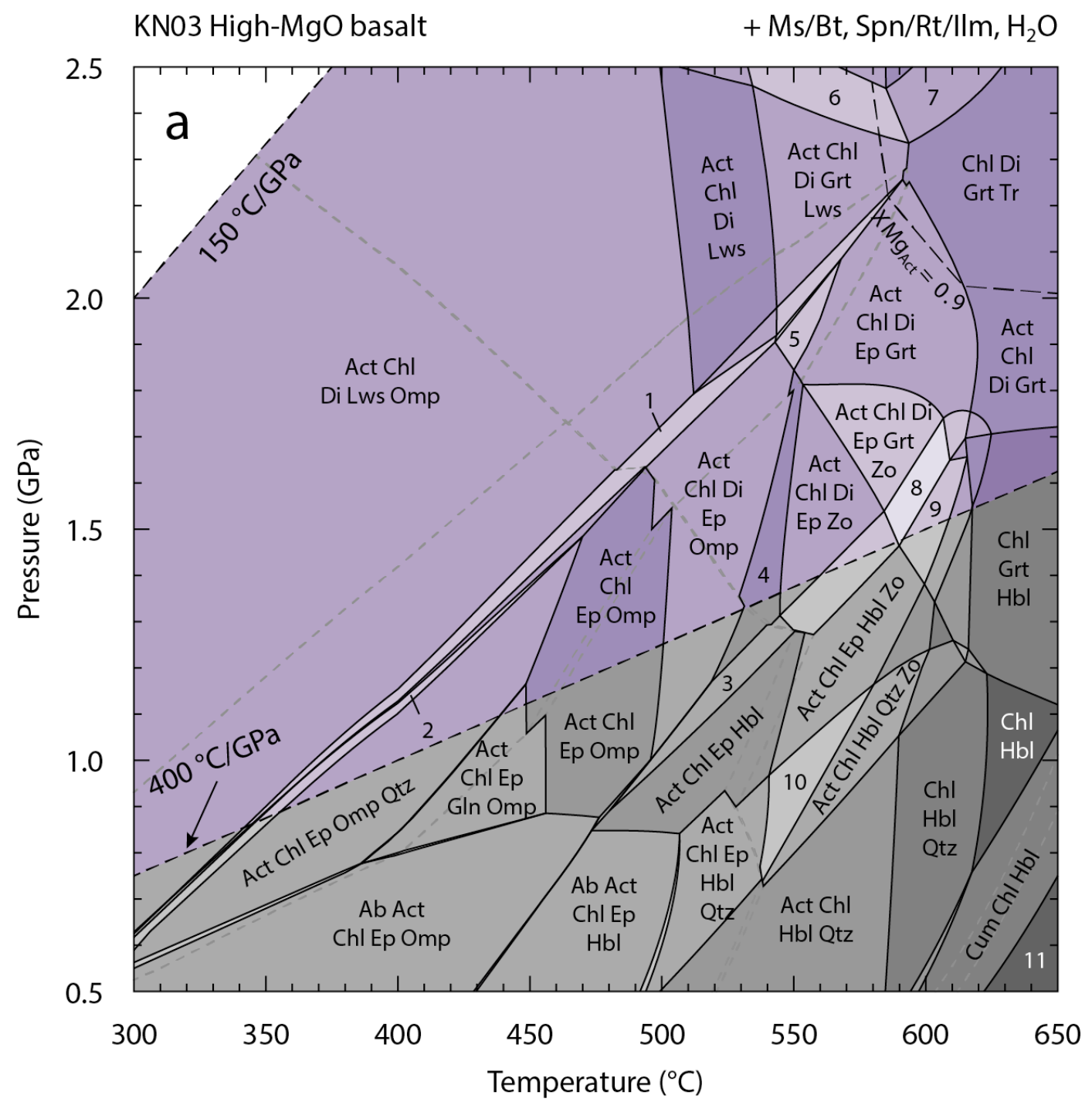

Pressure-temperature $(P-T)$ pseudosection calculated for the bulk-rock composition (Table S2) of Palaeoarchean high-MgO basalt sample 02MB256 from Kato and Nakamura (2003). Phase assemblage fields correspond to those shown in Fig. 1a in the main manuscript. Dashed line labelled $X \mathrm{Mg}_{\text {Act }}=0.9$ marks the division between actinolite $(<0.9)$ at low- $T /$ low $-P$ and tremolite $(>0.9)$ at high- $T /$ high- $P$. Some small, minor fields are unlabelled for clarity. Assemblage field boundaries marking the appearance or disappearance of muscovite, biotite, sphene, ilmenite, or rutile, are shown as grey dashed lines, which are omitted from the labelled assemblages due to their negligible calculated modal proportions (Fig. S2). Numbered fields are as follows: 1 - Act Chl Di Ep Lws Omp, 2 - Act Chl Ep Lws Omp Qtz, 3 - Act Chl Di Ep Hbl, 4 - Act Chl Di Ep, 5 - Act Chl Di Ep Grt Omp, 6 - Act Chl Di Grt Lws Tlc, 7 - Act Chl Di Grt Tlc, 8 - Act Chl Di Ep Grt Hbl Zo, 9 - Act Chl Ep Grt Hbl Zo, 10 - Act Chl Ep Hbl Qtz Zo, 11 - Cum Hbl. 
Figure S1b

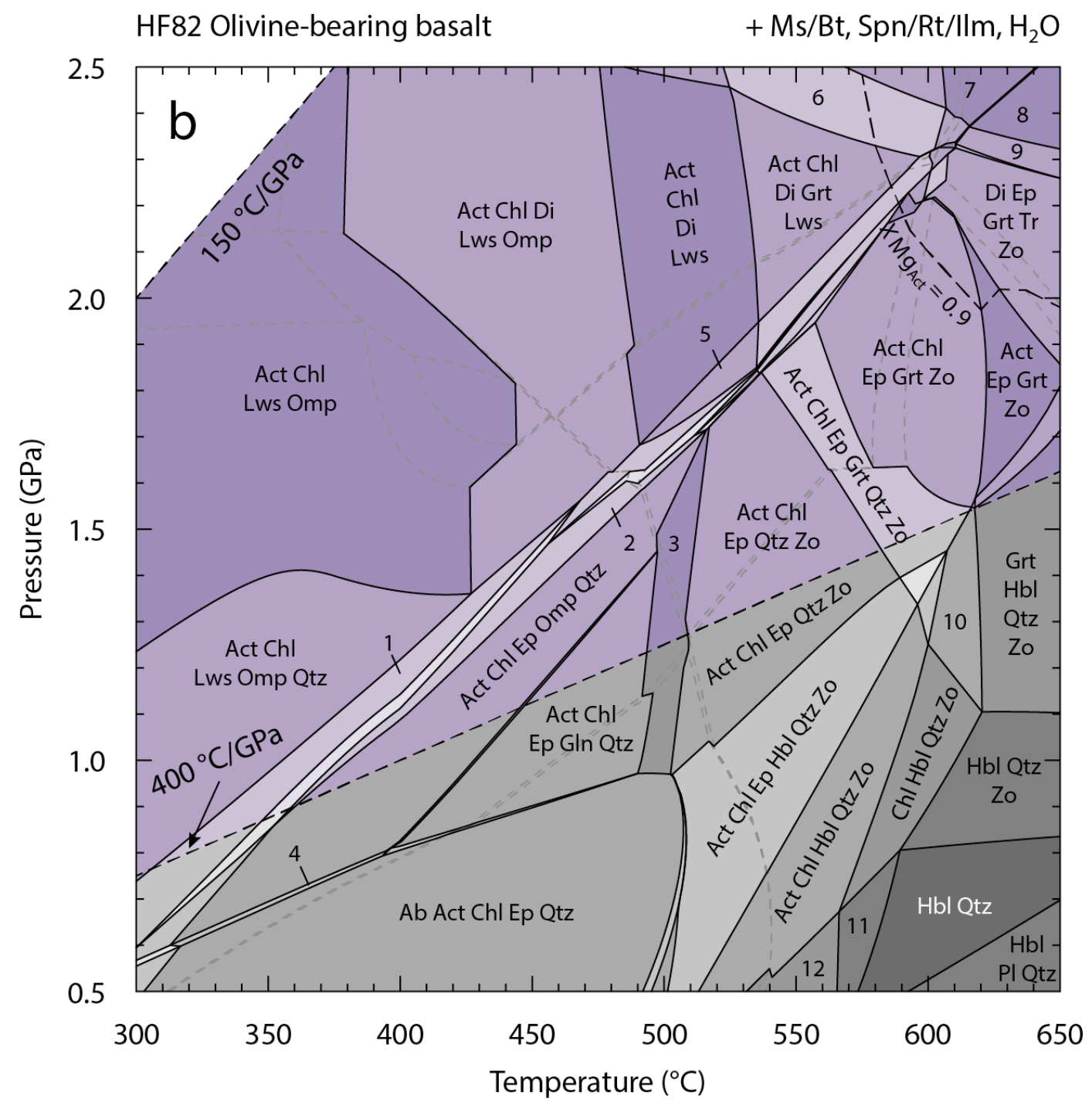

Pressure-temperature $(P-T)$ pseudosection calculated for the bulk-rock composition (Table S2) of Palaeoproterozoic olivine-bearing basalt sample CHK-MGO14 from Hynes and Francis (1982). Phase assemblage fields correspond to those shown in Fig. $1 \mathrm{~b}$ in the main manuscript. Dashed line labelled $X \mathrm{Mg}_{\text {Act }}=0.9$ marks the division between actinolite $(<0.9)$ at low- $T /$ low- $P$ and tremolite $(>0.9)$ at high- $T /$ high- $P$. Some small, minor fields are unlabelled for clarity. Assemblage field boundaries marking the appearance or disappearance of muscovite, biotite, sphene, ilmenite, or rutile, are shown as grey dashed lines, which are omitted from the labelled assemblages due to their negligible calculated modal proportions (Fig. S2). Numbered fields are as follows: 1 - Act Chl Di Lws Omp Qtz, 2 - Act Chl Ep Lws Omp Qtz, 3 - Act Chl Ep Qtz, 4 Ab Act Chl Ep Omp Qtz, 5 - Act Chl Di Ep Lws, 6 - Act Chl Di Grt Lws Tlc, 7 - Di Grt Lws Tlc, 8 - Di Grt Tlc Zo, 9 - Act Di Grt Tlc Zo, 10 - Chl Grt Hbl Qtz Zo, 11 - Chl Hbl Qtz, 12 Act Chl Hbl Qtz. 


\section{Figure S1c}

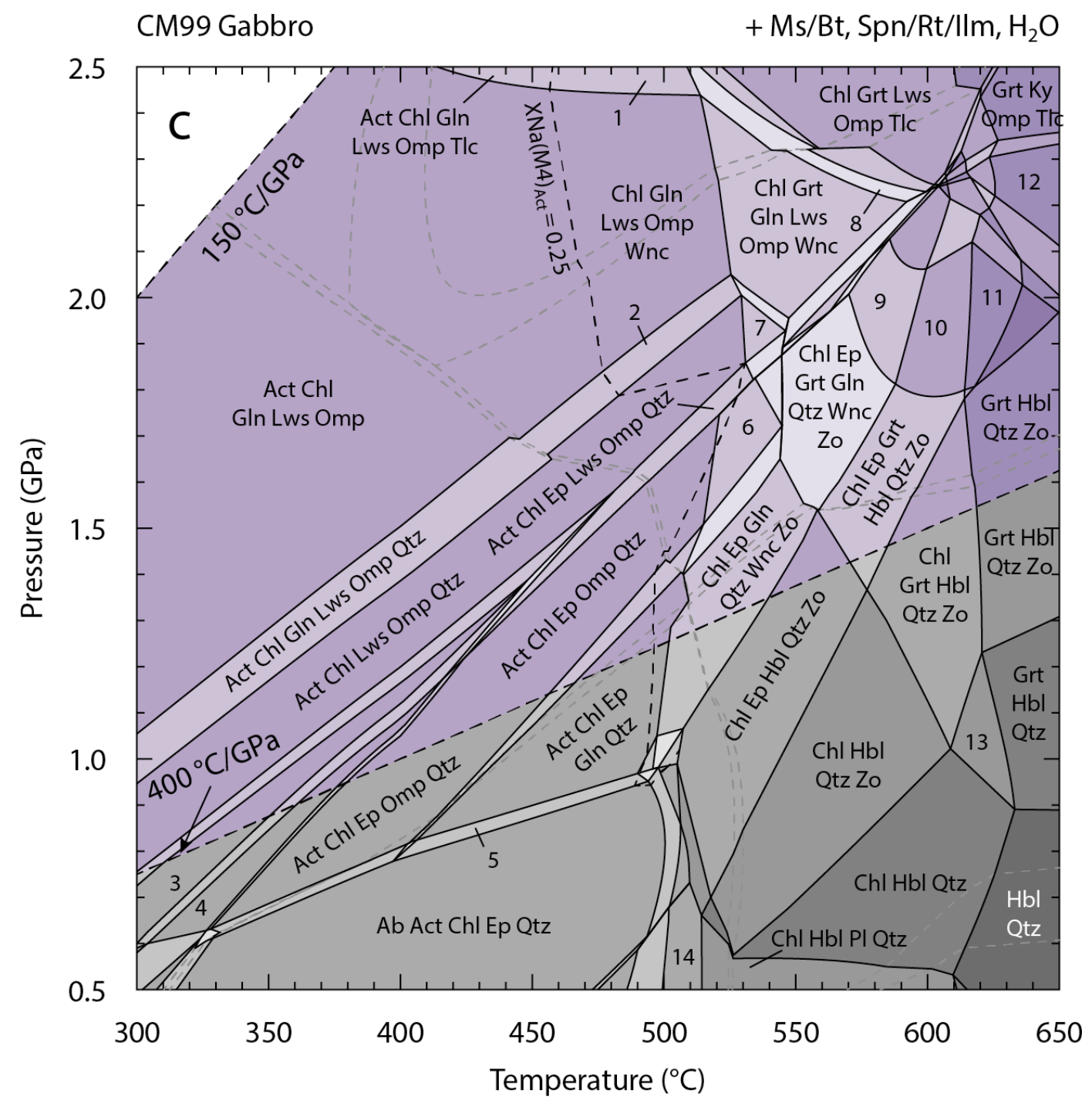

Pressure-temperature $(P-T)$ pseudosection calculated for the bulk-rock composition (Table S2) of Mesoproterozoic gabbro sample 769 from Condie and Myers (1999). Phase assemblage fields correspond to those shown in Fig. $1 \mathrm{c}$ in the main manuscript. Dashed line labelled $X \mathrm{Na}(\mathrm{M} 4)_{\mathrm{Act}}=$ 0.25 marks the division between actinolite $(<0.25)$ at low- $T /$ low- $P$ and winchite $(>0.25)$ at high$T /$ high- $P$. Some small, minor fields are unlabelled for clarity. Assemblage field boundaries marking the appearance or disappearance of muscovite, biotite, sphene, ilmenite, or rutile, are shown as grey dashed lines, which are omitted from the labelled assemblages due to their negligible calculated modal proportions (Fig. S2). Numbered fields are as follows: $1-\mathrm{Chl}$ Gln Lws Omp Tlc Wnc, 2 - Chl Ep Gln Lws Omp Wnc, 3 - Chl Di Lws Omp Qtz, 4 - Chl Di Ep Omp Qtz, 5 - Ab Act Chl Ep Gln Qtz, 6 - Act Chl Ep Omp Qtz Zo, 7 - Act Chl Gln Grt Lws Omp Qtz, 8 - Chl Grt Gln Lws Omp Tlc Wnc, 9 - Chl Ep Grt Gln Wnc Zo, 10 - Chl Ep Grt Wnc Zo, 11 - Ep Grt Wnc Zo, 12 - Grt Ky Omp Wnc, 13 - Chl Grt Hbl Qtz, 14 - Chl Ep Hbl Pl Qtz. 


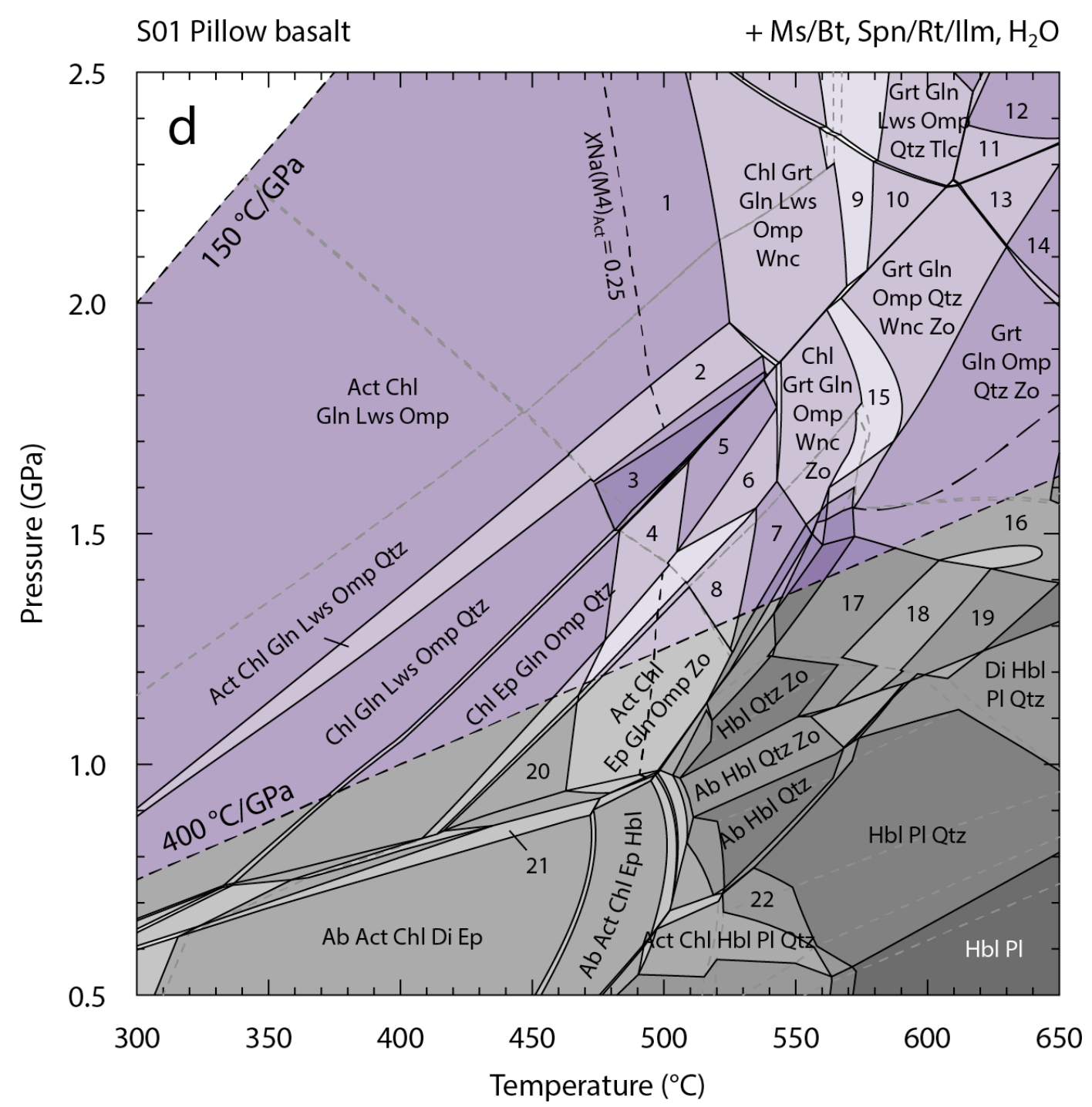

Pressure-temperature $(P-T)$ pseudosection calculated for the bulk-rock composition (Table S2) of Neoproterozoic pillow basalt sample BA-23 from Savov et al. (2001). Phase assemblage fields correspond to those shown in Fig. $1 \mathrm{~d}$ in the main manuscript. Dashed line labelled $X \mathrm{Na}(\mathrm{M} 4)_{\mathrm{Act}}=$ 0.25 marks the division between actinolite $(<0.25)$ at low- $T /$ low- $P$ and winchite $(>0.25)$ at high$T /$ high- $P$. The long-dashed line at $1.5-1.7 \mathrm{GPa}$ and $550-650{ }^{\circ} \mathrm{C}$ marks the $\mathrm{Hbl}-\mathrm{Gln}$ solvus extension. Some small, minor fields are unlabelled for clarity. Assemblage field boundaries marking the appearance or disappearance of muscovite, biotite, sphene, ilmenite, or rutile, are shown as grey dashed lines, which are omitted from the labelled assemblages due to their negligible calculated modal proportions (Fig. S5). Numbered fields are as follows: $1-$ Wnc Chl Gln Lws Omp, 2 - Wnc Chl Gln Lws Omp Qtz, 3 - Gln Lws Omp Qtz, 4 - Chl Ep Gln Omp Qtz Zo, 5 - Chl Gln Omp Qtz Zo, 6 - Chl Gln Omp Qtz Wnc Zo, 7 - Chl Gln Omp Wnc Zo, 8 - Chl Gln Omp Wnc, 9 - Chl Grt Gln Lws Omp Wnc Qtz, 10 -Grt Gln Lws Omp Wnc Qtz, 11 - Grt Gln Ky Omp Qtz Tlc, 12 - Grt Ky Omp Qtz Tlc, 13 - Grt Gln Ky Omp Qtz Wnc, 14 - Grt Gln Ky Omp Qtz, 15 - Chl Grt Gln Omp Qtz Wnc Zo, 16 - Grt Hbl Omp Qtz Zo, 17 - Hbl Omp Qtz Zo, 18 - Di Hbl Omp Qtz Zo, 19 - Di Hbl Qtz Zo, 20 - Act Chl Ep Gln Omp, 21 - Ab Act Chl Di Ep Gln, 22 - Act Hbl Pl Qtz. 


\section{Figure S2}
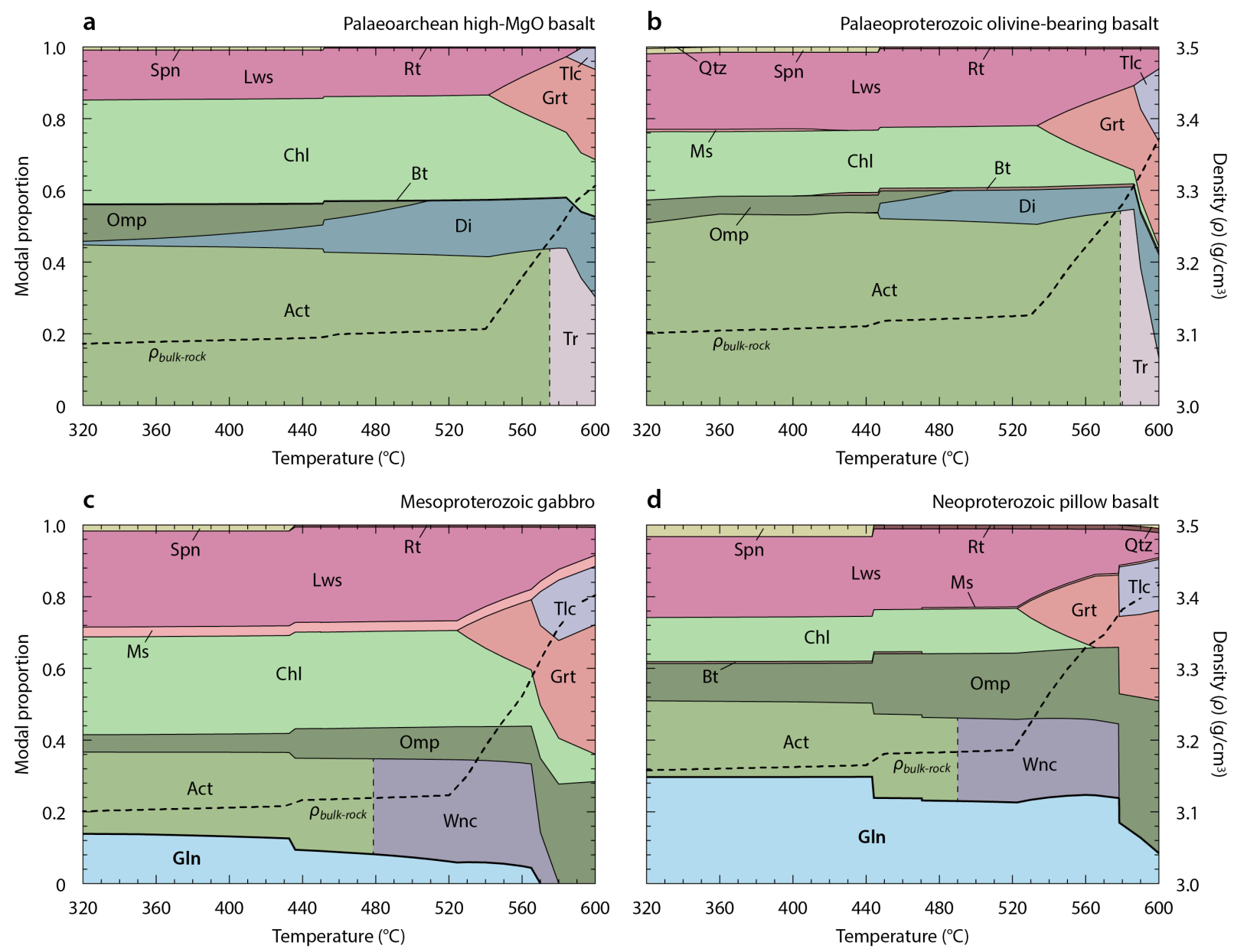

Modebox plots showing the changes in calculated mineral proportions and bulk-rock density during metamorphism along a cold geotherm $\left(250{ }^{\circ} \mathrm{C} / \mathrm{GPa}\right)$. a, Palaeoarchean high-MgO basalt sample 02MB256 (Kato and Nakamura, 2003); b, Palaeoproterozoic olivine-bearing basalt sample CHK-MGO14 (Hynes and Francis, 1982); c, Mesoproterozoic gabbro sample 769 (Condie and Myers, 1999); and d, Neoproterozoic pillow basalt sample BA-23 (Savov et al., 2001). Mineral abbreviations are after Kretz (1983). Bulk-rock density $\left(\mathrm{g} / \mathrm{cm}^{3}\right)$ is represented by a short-dashed line in each plot. Dashed line separating actinolite and tremolite in parts $\mathbf{a}$ and $\mathbf{b}$ represents the compositional isopleth $X \mathrm{Mg}_{\text {Act }}=0.9$, with actinolite having $<0.9$ and tremolite having $>0.9$. Dashed line separating actinolite and winchite in parts $\mathbf{c}$ and $\mathbf{d}$ represents the compositional isopleth $X \mathrm{Na}(\mathrm{M} 4)_{\text {Act }}=0.25$, with actinolite having $<0.25$ and winchite having $>0.25$. 


\section{Figure S3}
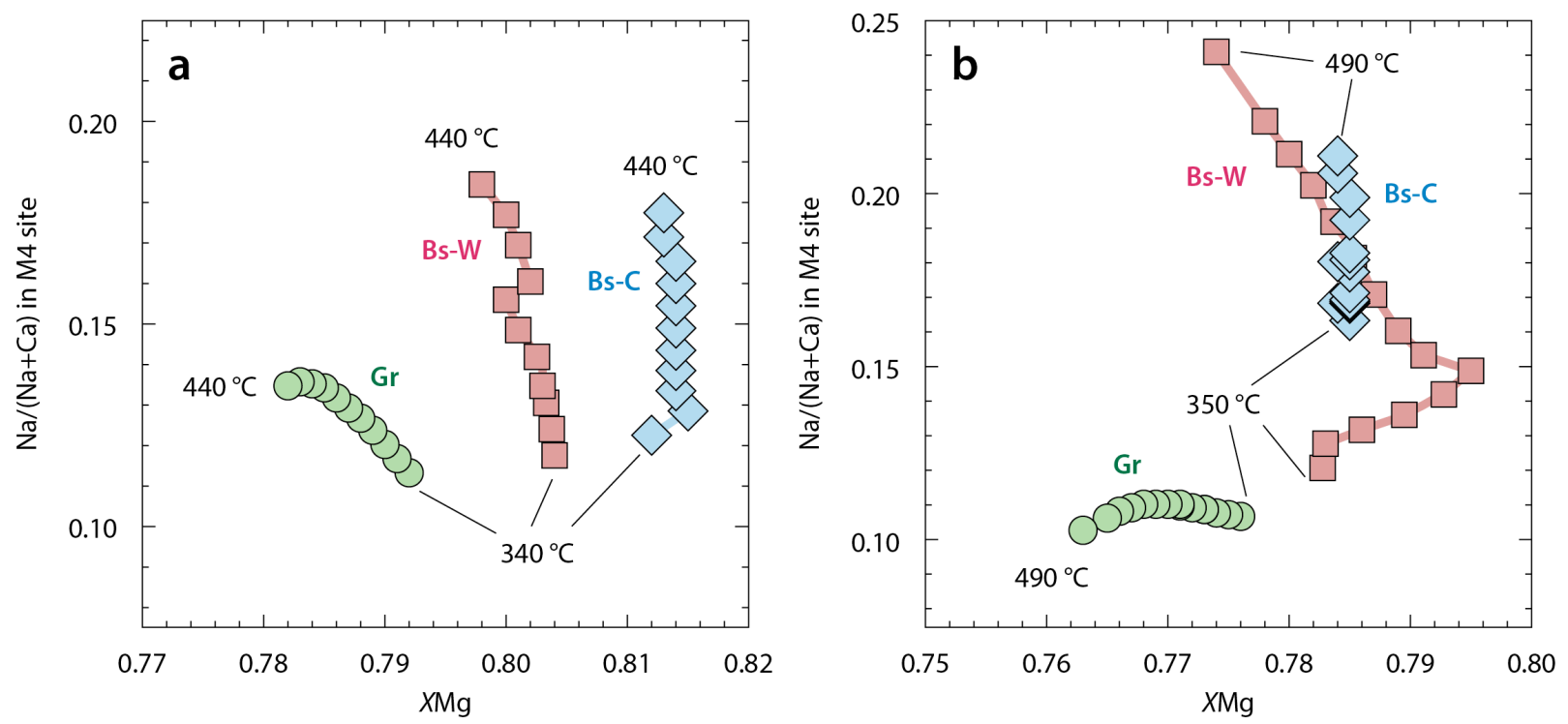

Calculated compositions of actinolite at different pressure-temperature conditions for a, Palaeoarchean high-MgO basalt and b, Palaeoproterozoic olivine-bearing basalt bulk-rock compositions. Abbreviations are as follows: $\mathrm{Bs}-\mathrm{C}=$ Blueschist-facies cold geotherm (250 ${ }^{\circ} \mathrm{C} / \mathrm{GPa}$; diamonds $)$, Bs-W = Blueschist-facies warm geotherm $\left(350{ }^{\circ} \mathrm{C} / \mathrm{GPa}\right.$; squares $), \mathrm{Gr}=$ Greenschist facies (0.6 GPa; circles). Symbols denote compositions at $10{ }^{\circ} \mathrm{C}$ intervals along each profile. $\mathrm{Na} /(\mathrm{Na}+\mathrm{Ca})$ in the $\mathrm{M} 4$ crystallographic site represents the proportion of "glaucophane" in the amphibole structure (Leake et al., 1997) and $X \mathrm{Mg}=\mathrm{Mg} /\left(\mathrm{Fe}^{2+}+\mathrm{Mg}\right)$. Representative compositions are given in Table S3. 


\section{Figure S4}

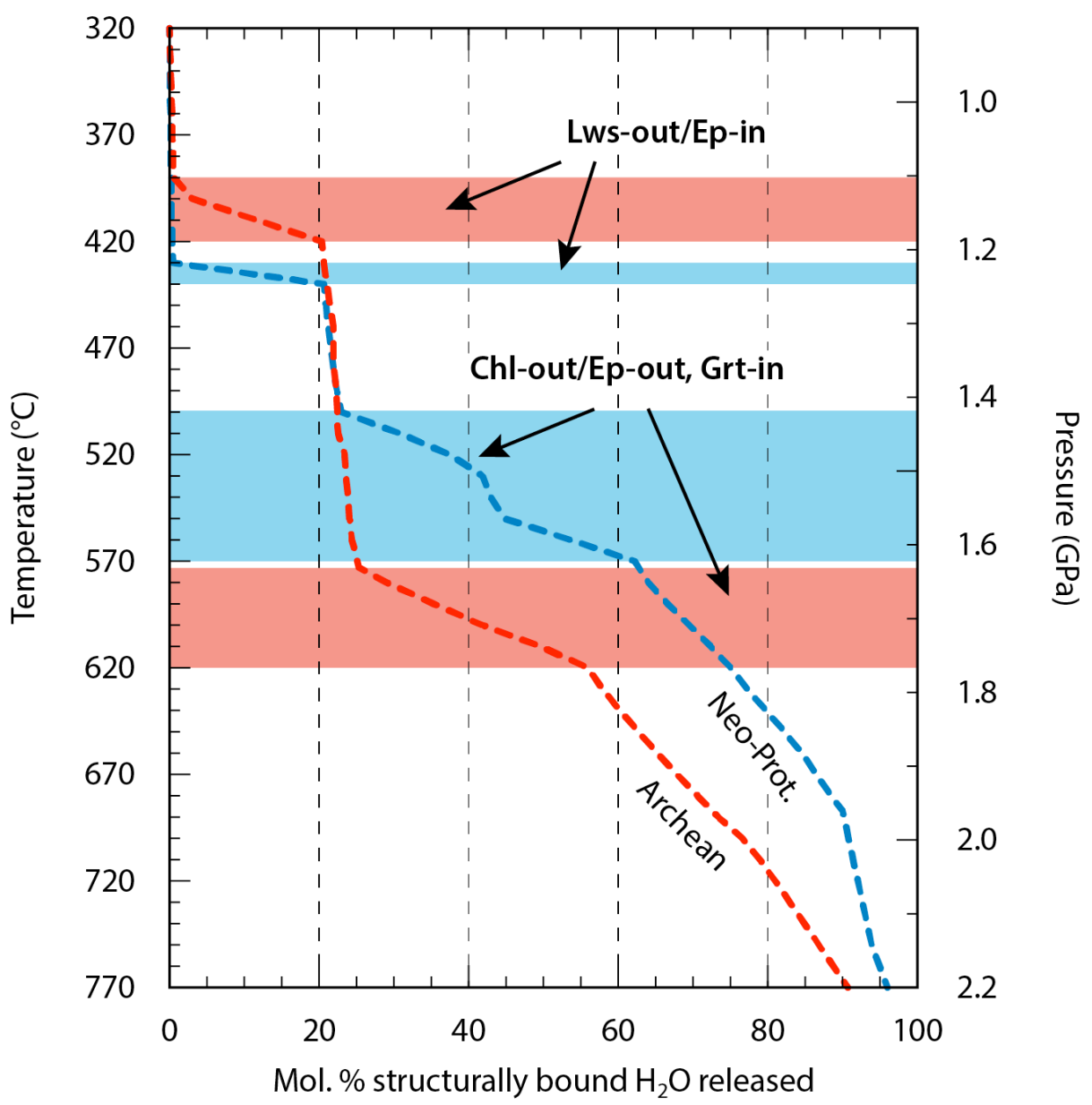

Pressure-temperature $(P-T)$ plot showing the molar percent of structurally bound $\mathrm{H}_{2} \mathrm{O}$ released during prograde metamorphism along a warm geotherm $\left(350{ }^{\circ} \mathrm{C} / \mathrm{GPa}\right)$. Samples comprise the Palaeoarchean high-MgO basalt composition of Kato and Nakamura (2003) (red dashed line labelled Archean), and the Neoproterozoic pillow basalt composition of Savov et al. (2001) (blue dashed line labelled Neo-Prot.). Red and blue horizontal bands represent approximate $P-T$ ranges over which important dehydration reactions occur for each sample. Percentages are normalized against the minimum absolute number of moles of $\mathrm{H}_{2} \mathrm{O}$ required to saturate the calculated equilibrium solid assemblage at $320^{\circ} \mathrm{C}$ and $9.1 \mathrm{kbar}$ (the first $P-T$ point along the calculated geotherm). These absolute values were calculated to be 16.3 and $14.5 \mathrm{~mol}$. \% $\mathrm{H}_{2} \mathrm{O}(5.93$ and 4.90 $\mathrm{wt} \%$ ) for the Archean high-MgO basalt and the Neoproterozoic pillow basalt, respectively. As such, the high-MgO basalt has the potential to hold $\sim 20 \%$ more structurally bound $\mathrm{H}_{2} \mathrm{O}$ in its bulk-rock composition than the Neoproterozoic basalt under equivalent fluid-saturated conditions. 


\section{References}

Abbott, D.H. \& Hoffman, S.E. Archaean plate tectonics revisited 1. Heat flow, spreading rate, and the age of subducting oceanic lithosphere and their effects on the origin and evolution of continents. Tectonics 3, 429-448.

Albarède, F. The survival of mantle geochemical heterogeneities. In van der Hilst, R., et al., eds, Structure, Composition, and Evolution of Earth's Mantle. Geophysical Monograph of the American Geophysical Union 160, 27-46 (2005).

Berry, A.J., Danyushevsky, L.V., O’Neill, H. St C., Newville, M. \& Sutton, S.R. Oxidation state of iron in komatiitic melt inclusions indicates hot Archaean mantle. Nature 455, 960-963 (2008).

Bickle, M.J. Heat loss from the earth: A constraint on Archean plate tectonics from the relation between geothermal gradients and the rate of plate production. Earth Planet. Sci. Lett. 40, 301-315 (1978).

Bradley, D.C. Passive margins through earth history. Earth-Sci. Rev. 91, 1-26 (2008).

Christie, D.M., Carmichael, I.S.E. \& Langmuir, C.H. Oxidation states of mid-ocean ridge basalt glasses. Earth Planet. Sci. Lett. 79, 397-411 (1986).

Coggon, R. \& Holland, T.J.B. Mixing properties of phengitic micas and revised garnet-phengite thermobarometers. J. Metamorp. Geol. 20, 683-696 (2002).

Condie, K.C. \& Myers, J.S. Mesoproterozoic Fraser Complex: geochemical evidence for multiple subduction-related sources of lower crustal rocks in the Albany-Fraser Orogen, Western Australia. Aust. J. Earth Sci. 46, 875-882 (1999).

Condie, K.C., Pisarevsky, S.A., Korenega, J. \& Gardoll, S. Is the rate of supercontinent assembly changing with time? Precambrian Res. 259, 278-289 (2015).

Dewey, J.F. \& Windley, B.F. Growth and differentiation of continental crust. Philos. T. R. Soc. Lond. S-A. 301, 189-206 (1981).

Diener, J.F.A. \& Powell, R. Revised activity-composition models for clinopyroxene and amphibole. J. Metamorp. Geol. 30, 131-142 (2012).

Furnes, H., Dilek, Y. \& de Wit, M. Precambrian greenstone sequences represent different ophiolite types. Gondwana Res. 27, 649-685 (2014).

Ganne, J., et al. Modern-style plate subduction preserved in the Palaeoproterozoic West African craton. Nature Geosci. 5, 60-65 (2011).

Herzberg, C., Condie, K. \& Korenaga, J. Thermal history of the Earth and its petrological expression. Earth Planet. Sci. Lett. 292, 79-88 (2010).

Holland, T.J.B. \& Powell, R. An internally-consistent thermodynamic dataset for phases of petrological interest. J. Metamorp. Geol. 16, 309-344 (1998).

Holland, T.J.B. \& Powell, R. Activity-composition relations for phases in petrological calculations: an asymmetric multicomponent formulation. Contrib. Mineral. Petrol. 145, 492-501 (2003). 
Holland, T.J.B., Baker, J.M. \& Powell, R. Mixing properties and activity-composition relationships of chlorites in the system $\mathrm{MgO}-\mathrm{FeO}-\mathrm{Al}_{2} \mathrm{O}_{3}-\mathrm{SiO}_{2}-\mathrm{H}_{2} \mathrm{O}$. Eur. J. Mineral. 10, 395-406 (1998).

Hynes, A.J. \& Francis, D.M. A transect of the early Proterozoic Cape Smith foldbelt, New Quebec. Tectonophysics 88, 23-59 (1982).

Kato, Y. \& Nakamura, K. Origin and global tectonic significance of Early Archean cherts from the Marble Bar greenstone belt, Pilbara Craton, Western Australia. Precambrian Res. 125, 191-243 (2003).

Korenaga, J. Archean geodynamics and the thermal evolution of Earth. In Benn, K. et al., eds, Archean Geodynamics and Environments. American Geophysical Union, Washington, D.C. (2006).

Korenaga, J. Urey Ratio and the structure and evolution of the Earth's mantle. Rev. Geophys. 46, RG2007 (2008).

Korenaga, J. Initiation and evolution of plate tectonics on Earth: Theories and observations. Annu. Rev. Earth Sci. 41, 117-51 (2013).

Kretz, P. Symbols for rock-forming minerals. Am. Mineral. 68, 277-279 (1983).

Leake, B.E. et al. Nomenclature of amphiboles: Report of the Subcommittee on Amphiboles of the International Mineralogical Association, Commission on New Minerals and Mineral Names. Am. Mineral. 82, 1019-1037 (1997).

Moyen, J.F., Stevens, G. \& Kisters, A. Record of mid-Archaean subduction from metamorphism in the Barbeton terrain, South Africa. Nature 442, 559-562 (2006).

Nisbet, E.G. \& Fowler, C.M.R. Model for Archean plate tectonics. Geology 11, 376-379 (1983).

Padhi, C., Korenaga, J. \& Ozima, M. Thermal evolution of Earth with xenon degassing: a selfconsistent approach. Earth Planet. Sci. Lett. 1-9, 341-344, (2012)

Palin, R.M., Weller, O.M., Waters, D.J. \& Dyck, B. Quantifying geological uncertainty in metamorphic phase equilibria modelling; a Monte Carlo assessment and implications for tectonic interpretations. Geosci. Front. (in press), doi: 10.1016/j.gsf.2015.08.005.

Peck, W.H., Valley, J.W., Wilde, S.A. \& Graham, C.M. Oxygen isotope ratios and rare earth elements in 3.3 to $4.4 \mathrm{Ga}$ zircons: Ion microprobe evidence for high $\delta^{18} \mathrm{O}$ continental crust and oceans in the Early Archean. Geochim. Cosmochim. Acta 65, 4215-4229 (2001).

Powell, R. \& Holland, T.J.B. An internally consistent thermodynamic dataset with uncertainties and correlations: 3. Application to geobarometry, worked examples, and a computer program. J. Metamorp. Geol. 6, 173-204 (1988).

Powell, R. \& Holland, T.J.B. On thermobarometry. J. Met. Geol. 26, 155-179 (2008).

Savov, I., Ryan, J., Haydoutov, I. \& Schijf, J. Late Precambrian Balkan-Carpathian ophiolite - a slice of the Pan-African ocean crust? Geochemical and tectonic insights from the Tcherni Vrah and Deli Jovan massifs, Bulgaria and Serbia. J. Volcanol. Geoth. Res. 110, 299-318 (2001). 
Schmidt, M.W., \& Poli, S. Experimentally based water budgets for dehydrating slabs and consequences for arc magma generation. Earth Planet. Sci. Lett. 163, 361-379 (1998).

Solomon, S.C., Sleep, N.H. \& Richardson, R.M. On the forces driving plate tectonics: Inferences from absolute plate velocities and intraplate stress. Geophys. J. Roy. Astr. S. 42, 769-801 (1975).

Syracuse, E.M., van Keken, P.E. \& Abers, G.A. The global range of subduction zone thermal models. Phys. Earth Planet. In. 183, 73-90 (2010).

Van Krankendonk, M.J. \& Kirkland, C.L. Orogenic climax of Earth: The 1.2-1.1 Ga Grenvillian superevent. Geology 7, 735-738 (2013).

White, R.W., Powell, R., Holland, T.J.B. \& Worley, B.A. The effect of $\mathrm{TiO}_{2}$ and $\mathrm{Fe}_{2} \mathrm{O}_{3}$ on metapelitic assemblages at greenschist and amphibolite facies conditions: mineral equilibria calculations in the system $\mathrm{K}_{2} \mathrm{O}-\mathrm{FeO}-\mathrm{MgO}-\mathrm{Al}_{2} \mathrm{O}_{3}-\mathrm{SiO}_{2}-\mathrm{H}_{2} \mathrm{O}-\mathrm{TiO}_{2}-\mathrm{Fe}_{2} \mathrm{O}_{3}$. J. Metamorp. Geol. 18, 497-511 (2000).

White, R.W., Powell, R. \& Holland, T.J.B. Progress relating to calculation of partial melting equilibria for metapelites. J. Metamorp. Geol. 25, 511-527 (2007). 


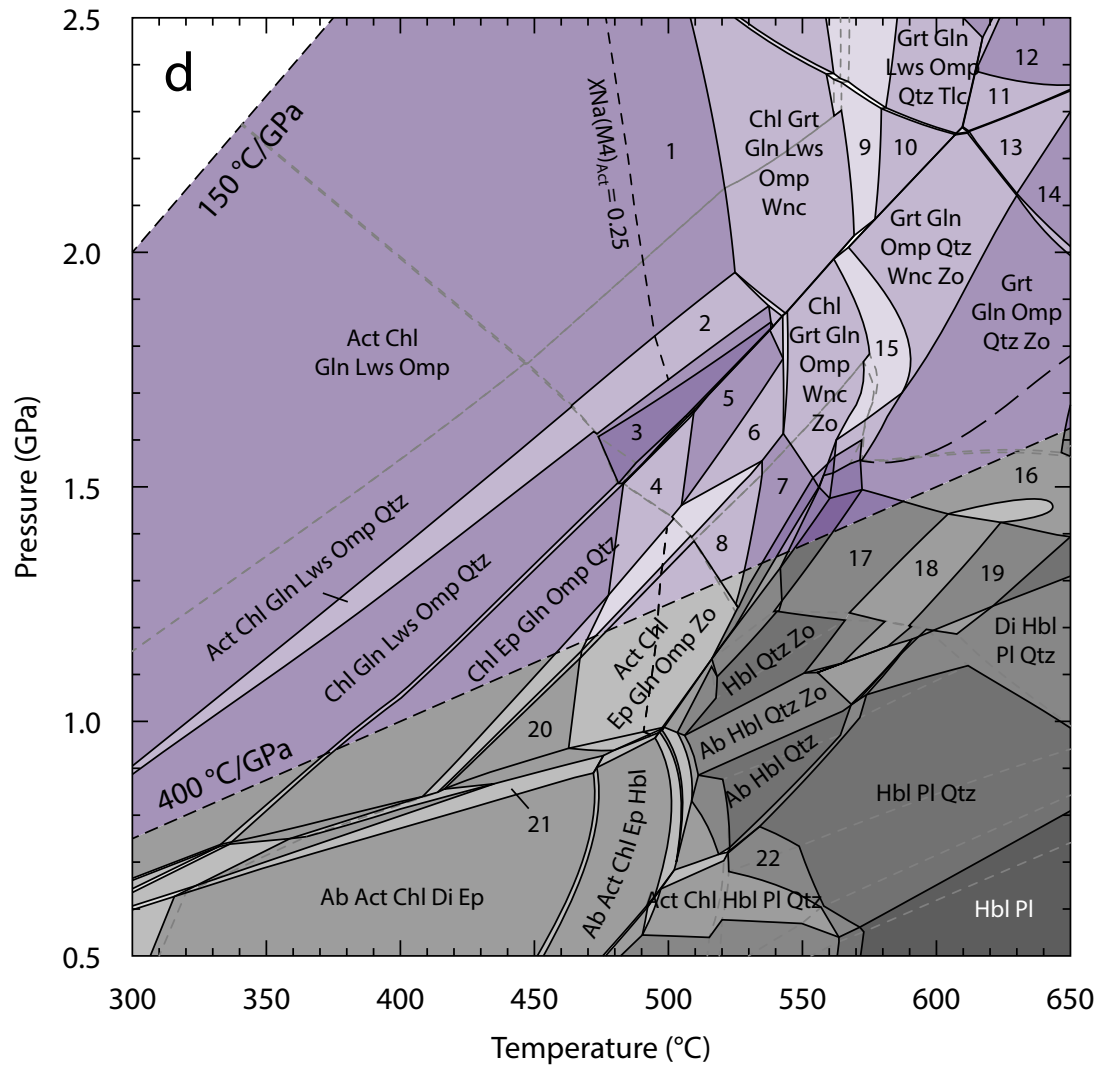


CM99 Gabbro

$+\mathrm{Ms} / \mathrm{Bt}, \mathrm{Spn} / \mathrm{Rt} / \mathrm{Im}, \mathrm{H}_{2} \mathrm{O}$

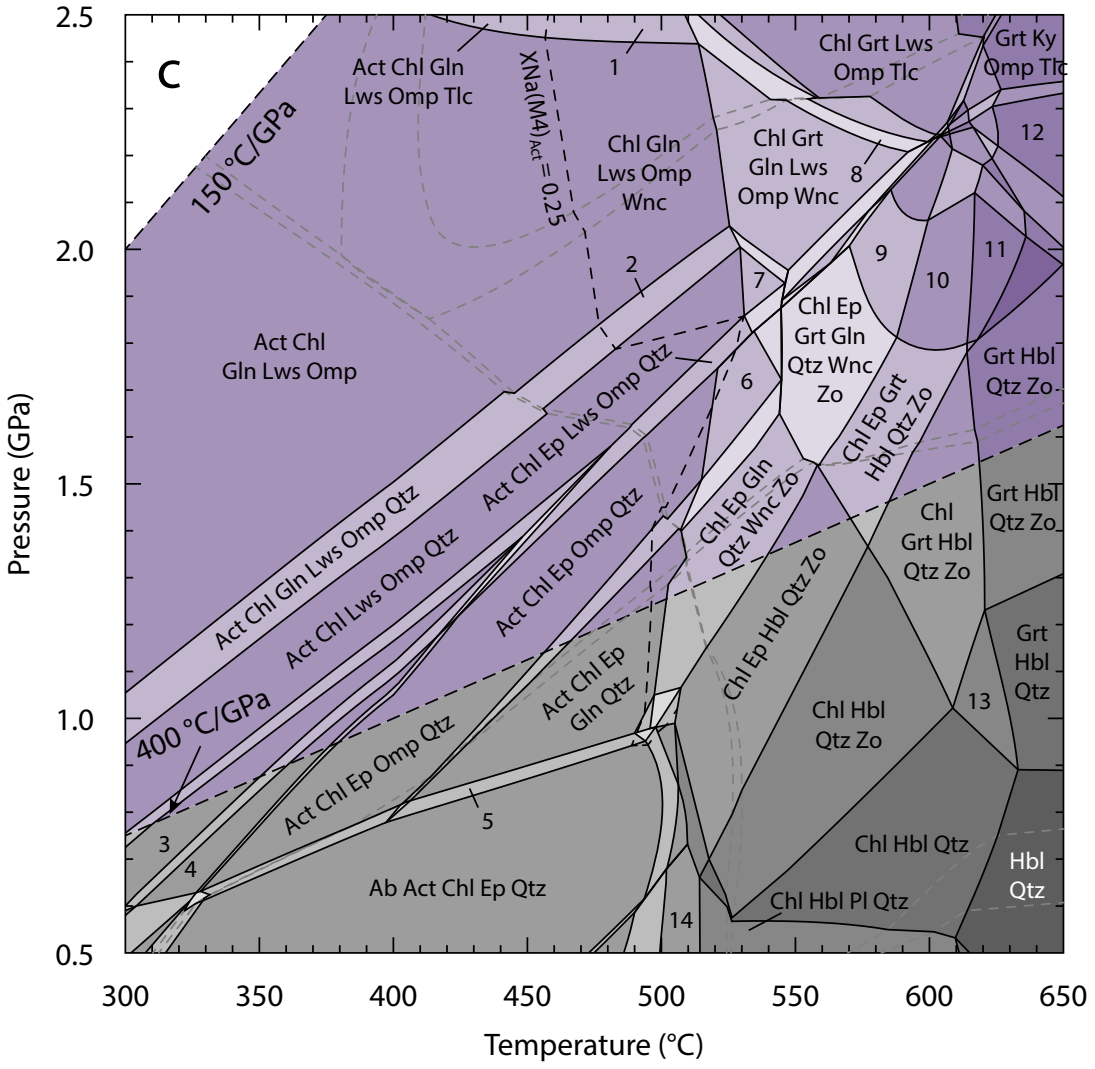


HF82 Olivine-bearing basalt

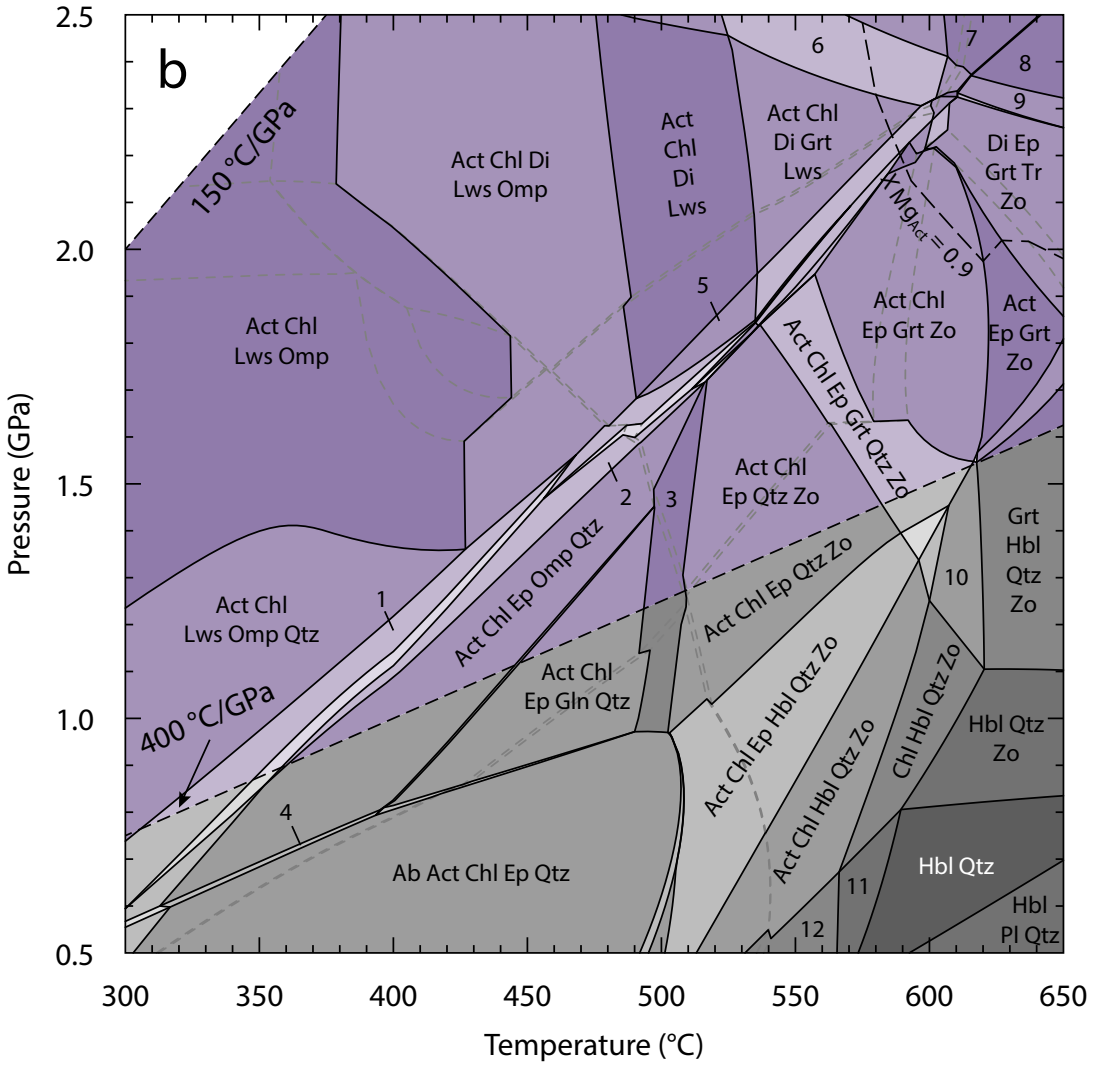


KN03 High-MgO basalt

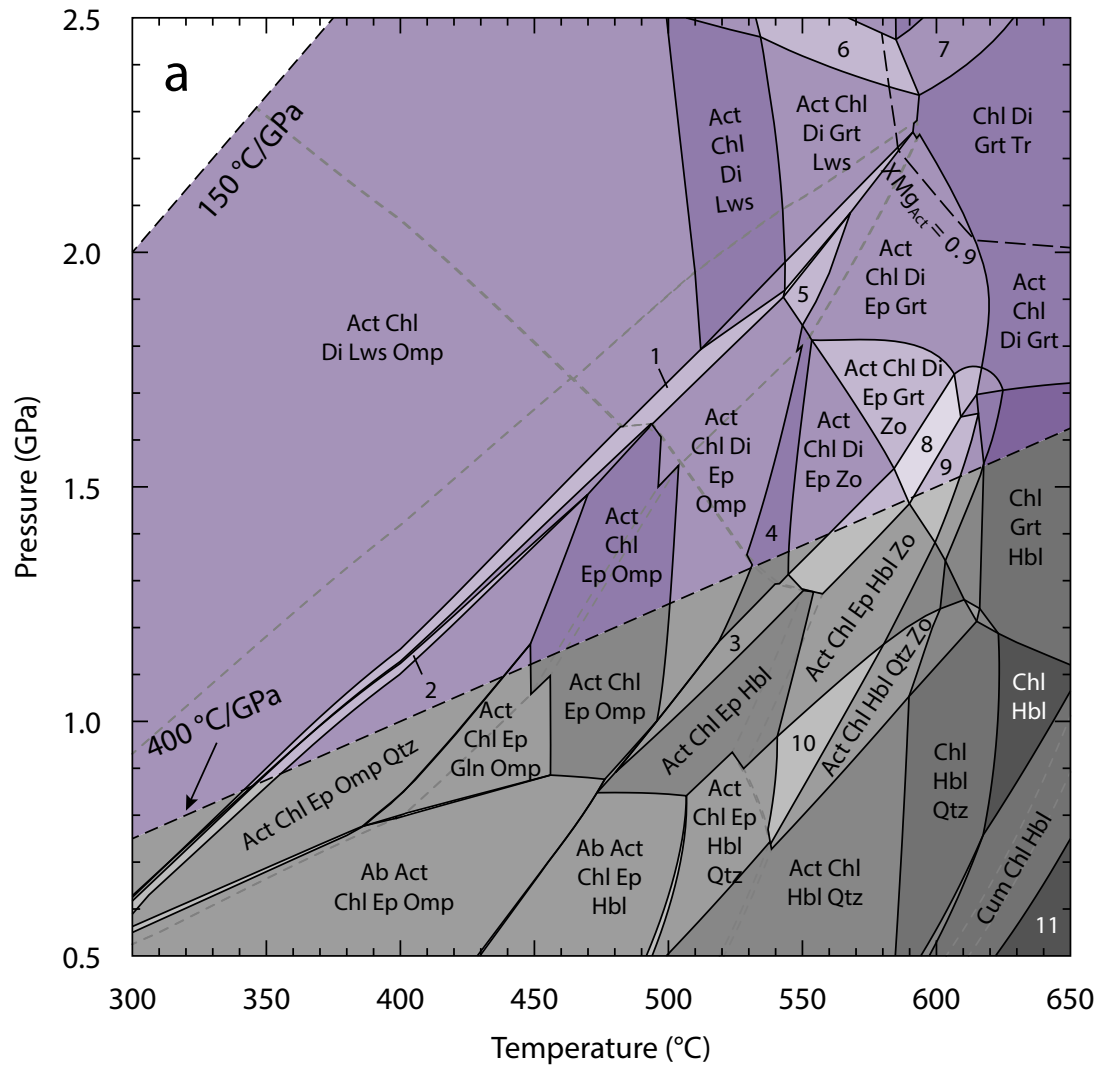




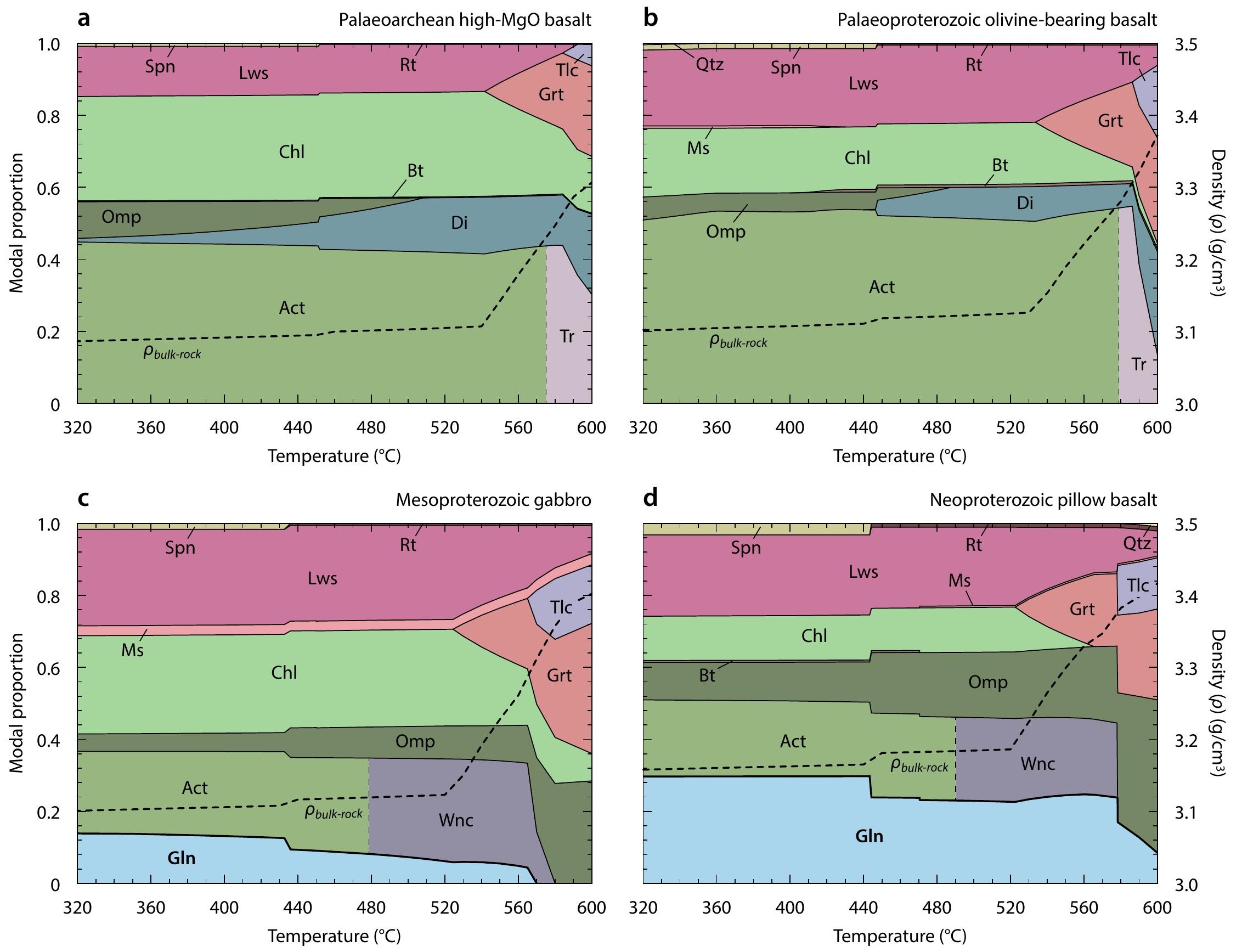



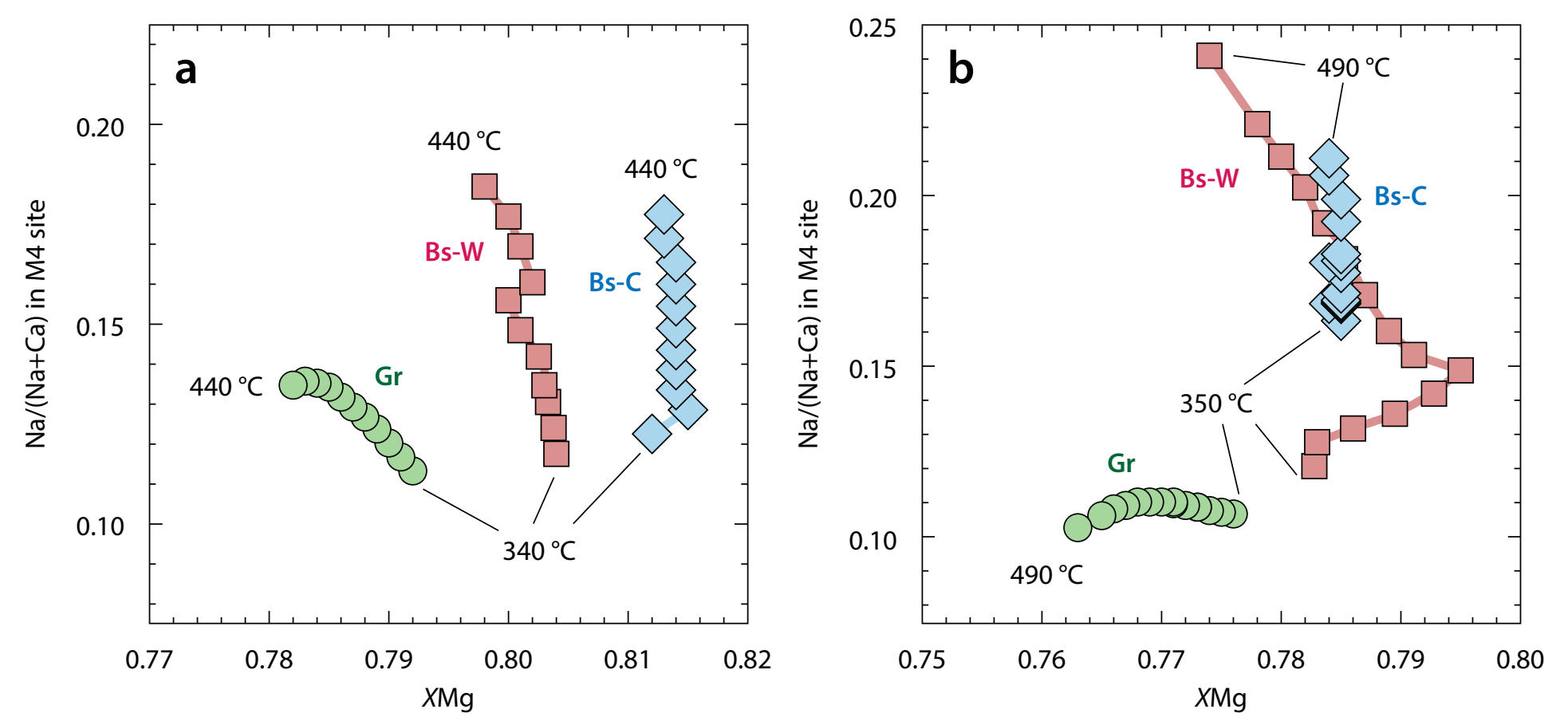


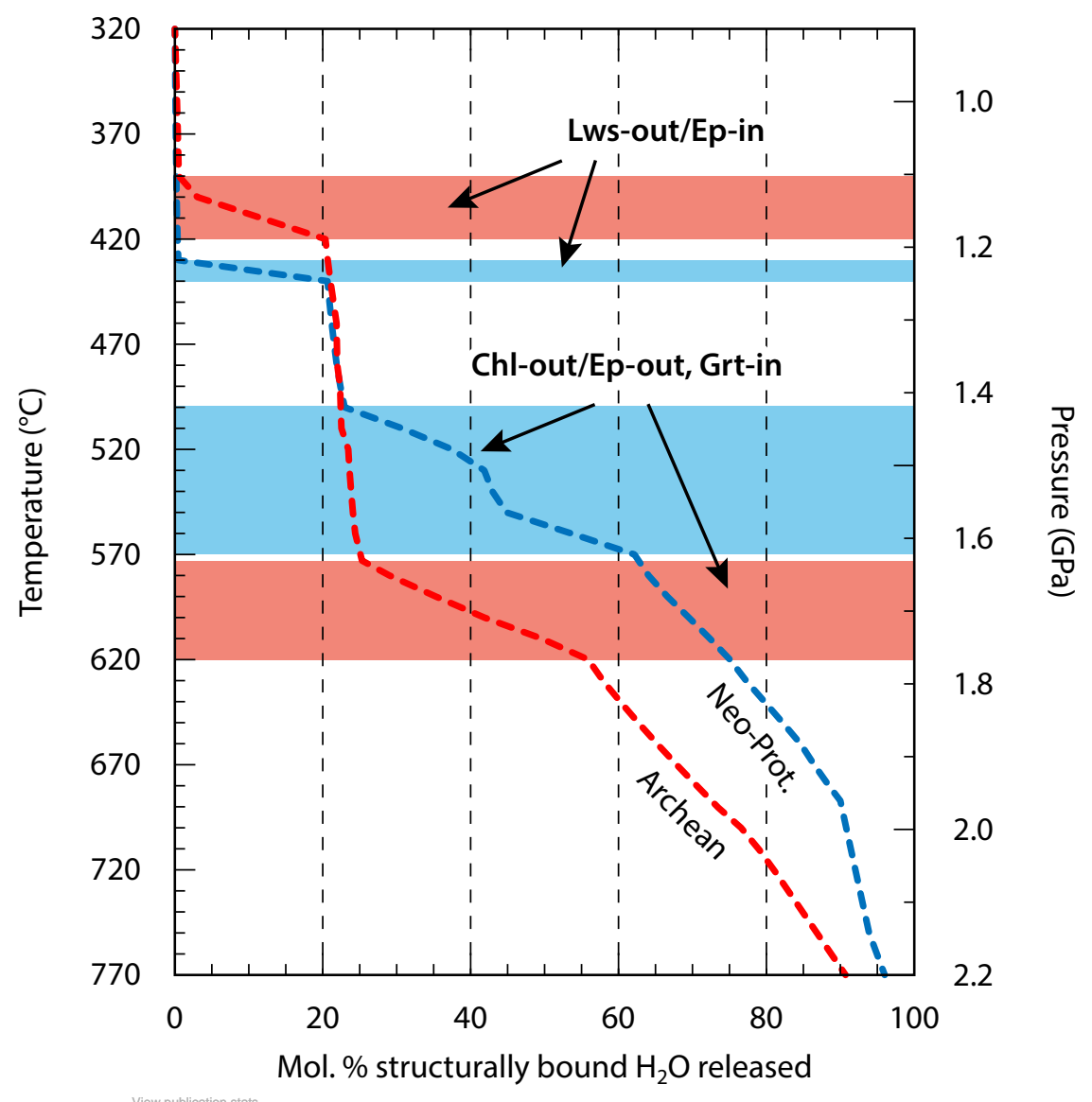

